\title{
Idegen szavak félautomatikus elemzése autentikus és fordított orvosi szövegekben: fordítási stratégiák angolról franciára és magyarra fordított betegtájékoztatók tükrében
}

\author{
Mány Dániel
}

\author{
manydanie191@gmail.com \\ ELTE Nyelvtudományi Doktori Iskola \\ Fordítástudományi Doktori Program
}

Cervical dystonia (or spasmodic torticollis) is

the most common form of focal or localized dystonia.

Neurological in origin, it is characterized by muscular spasms...

(Ipsen weboldal 2018)

Kivonat: A jelen leíró jellegü, feltáró tanulmány középpontjában az idegen szavak jelensége áll, azon belül pedig ezen orvostudományi terminusok előfordulása és fordítása autentikus angol, valamint angolról magyarra és franciára fordított betegtájékoztatók párhuzamos korpuszában. Az idegen szavak gyakorisága nyelvenként eltérö, ezért a fordítónak szem elött kell tartania a laikus célnyelvi olvasó feldolgozási erőfeszítését. A vizsgált korpuszban az angolra jellemző a legkevésbé az idegen szavak használata. Az angolhoz képest több idegen szó azonosítható a francia alkorpuszban, a legtöbb idegen szó a magyar alkorpuszban van. Mindez főként a vizsgált nyelvek szókészleti különbségeivel magyarázható. Az elemzés során összesen $5+1$ fordítási stratégiát állapítottam meg, amelyek tekintetében a fordító törekszik az idegen szavak fordításakor megfelelni a laikus célnyelvi olvasó

Az Innovációs és Technológiai Minisztérium ÚNKP-20-4 kódszámú Új Nemzeti Kiválóság Programjának a Nemzeti Kutatási, Fejlesztési és Innovációs Alapból finanszírozott szakmai támogatásával készült.

Mány Dániel: Idegen szavak félautomatikus elemzése autentikus és fordított orvosi szövegekben: fordítási stratégiák angolról franciára és magyarra fordított betegtájékoztatók tükrében. In: Robin E., Seidl-Péch O. (szerk.) 2020. Fókuszban a forditott és a tolmácsolt szöveg: korpuszalapú fordításkutatás Magyarországon. Segédkönyvek a nyelvi közvetítésről I. Budapest: ELTE BTK Fordítástudományi Doktori Program, MANYE Fordítástudományi Szakosztály. DOI: $\underline{\text { https://doi.org/10.36252/Nyelvikozvsegedkonyv1.6 }}$ 
és az egészségügyi személyzet elvárásainak. Jelen tanulmány a 2018-as TransELTE Konferenciakötetben megjelenő cikkem bővített változata.

Kulcsszavak: betegtájékoztatók, fordítási stratégiák, idegen szavak, laikus célközönség, párhuzamos korpusz

\section{Bevezetés}

Jelen leíró jellegű, feltáró tanulmány középpontjában a fenti mottóban is fellelhető idegenítő stratégia áll, azon belül pedig ezen orvostudományi terminusok és/vagy szinonimáik előfordulása autentikus angol, valamint angolról magyarra és franciára fordított betegtájékoztatókban.

Kutatásomat az motiválta, hogy bár számos kutató (pl.: Bősze 2011, Heltai 2004, Jiménez-Crespo és Tercedor Sánchez 2017, stb.) foglalkozott az idegen szavak, a tudományos terminusok és a köznyelvi szavak nyelv- és fordítástudományi vonatkozásaival az általam vizsgált három nyelv mindegyikén, tudomásom szerint mindeddig nem került sor az angolról magyarra és franciára fordított szövegek átfogó, összevető vizsgálatára az idegen szavak gyakorisága, eloszlása és a rájuk jellemző fordítási stratégiák tükrében.

Ahogy azt a továbbiakban bemutatom, az idegen szavak előfordulásukat, gyakoriságukat és eredetüket tekintve nyelvközösségekként, kultúrákként, müfajokként, szövegtípusokként eltérök lehetnek, még az orvosi szaknyelven belül is. Különösen érdemesnek tartom az idegen szavak vizsgálatát forrásnyelvi szövegeken (FNYSZ), illetve azok öszszevetését célnyelvi szövegekkel (CNYSZ), ahol a fordító feladata pontosan a nyelvek és kultúrák közötti közvetítés. Korábbi vizsgálatok rávilágítanak, hogy az orvosi szakfordítás a fordítói piac egyik legjelentősebb ágazata (Montalt Resurrecció és González Davies 2007), s ennek köszönhetően a fordítástudomány kedvelt kutatási területe (Montalt Resurrecció 2011). Éppen ezért úgy gondolom, hogy kiemelkedően fontos a területen végzett leíró kutatások folyamatos szorgalmazása. Zethsen (2004: 139) rámutat, hogy bár hipotézisének alátámasztására további vizsgálatok szükségesek, a latin eredetű terminusok direkt átvitelre angolról dánra orvos-laikus kommunikációban jelentősen megnehezítheti az olvasó feldolgozási erőfeszítését, sőt, érthetetlenné is teheti a szöveget. Jelen tanulmány 
igyekszik szükíteni az említett kutatási ürt, annál is inkább, mert a korábban végzett, a jelen tanulmány szempontjából releváns vizsgálatok (Nisbeth Jensen és Zethsen 2012, Jiménez-Crespo és Tercedor Sánchez 2017) ellentmondásos eredményekről számolnak be. Tanulmányom eredményeit összehasonlítom az imént említett, korábbi vizsgálatok eredményeivel.

A betegtájékoztatók olyan orvosok által írt, laikusoknak szóló dokumentumok, amelyek jó lehetőséget adnak annak vizsgálatára, hogy az orvos-laikus közötti írott kommunikáció szövegeinél milyen fordítói stratégiák (pl.: explicitáció, implicitáció, orvostudományi terminus kerülése stb.) figyelhetők meg. A jelen tanulmány célja ezen stratégiák azonosítása és leírása. A stratégiák leírásának, tipizálásának célja gyakorló fordítók, fordítást oktató tanárok, nyelvtanulók segítése, valamint új információ gyüjtése az idegen eredetű terminusok fordítási stratégiáiról a már meglévő ismeretek, korábbi kutatások eredményeinek tükrében.

Fontos kutatási kérdés számomra, hogy a fordító hogyan jár el az idegen eredetü orvostudományi terminusok fordításakor. Legalább ilyen fontosnak tartom, hogy az idegen szavaknak más stilisztikai értéke van, mint a köznyelvi szavaknak. Ennek az orvosi szaknyelvben azért van kiemelkedő szerepe, mert az egészségügyi szakdolgozók a kommunikáció során elkerülési mechanizmusokat alkalmaznak. Amikor általuk kényesnek, nehéznek ítélt tényekről kell tájékoztatniuk a betegeket (Cselovszkyné Tarr 1999), eufemisztikus hatást kelthetnek, ha az általuk is ismert köznyelvi szó helyett tudományos terminust használnak. A vizsgálat további célja annak leírása, hogy az idegen eredetü, eufemisztikus hatást keltő tudományos terminusok hogyan jelentkeznek a forrásnyelvi és a célnyelvi szövegben.

\section{EIméleti háttér}

Mint minden nyelvben, sőt, mint minden szaknyelvben, az angol, francia és magyar orvosi szaknyelvben is vannak idegen szavak. A népek, népcsoportok folyamatosan érintkeznek egymással, és az új fogalmak, tárgyak megnevezésére idegen eredetủ szavakat vesznek 
és adnak át. A nem belső keletkezésü szóállományban megkülönböztetjük egymástól a jövevényszó vagy kölcsönszó és az idegen szó fogalmát. Az idegen szó és a jövevényszó közötti különbség abban rejlik, hogy míg az idegen szó idegenszerúségét a nyelvközösség legtöbb tagja érzékeli, a jövevényszó nem idegenszerü, az átvevő nyelv rendszerébe beilleszkedett, a nyelvközösség számára nem idegen hatású. Természetesen az idegen szavak idővel ugyanúgy jövevényszavakká válhatnak (Fazekas 2007): bár a vírus, doktor, fisztula, diftéria szavak mind latin eredetủek, véleményem szerint az első kettő nem hat idegenszerüen a nyelvközösség döntö többségének.

\subsection{Idegen szavak, tudományos terminusok és köznyelvi szavak}

Jelen tanulmány központi kérdése az általam vizsgált orvosi szaknyelvekben megjelenő idegen szavak, tehát a laikus olvasó számára feltehetőleg idegenszerüleg ható terminusok jelensége. Úgy gondolom, hogy a vizsgált nyelvekben a görög, latin és angol (LGA) eredetű idegen szavakat érdemes vizsgálni. Ennek oka, hogy az egyetemes orvostudomány az ókori görög, majd a görög-latinná alakult szakkifejezések tárán alapszik, és erre támaszkodik ma is (Bősze 2011: 370-371). A 20. század második felében az angol vált a nemzetközi közös nyelvvé. A tudományos ismeretek folyamatos bővülése nap mint nap új terminusokat, kifejezéseket szül. Az orvostudomány lingua francája ma egyértelmủen az angol, amely ugyanazt a szerepet tölti be a tudományos kommunikációban, mint az ókorban a görög, a középkorban a latin (Varga 2014: 35). Az újonnan keletkezett terminusokat angolul nevezik el, amelyek beépülnek a nemzetek tudományos nyelveibe (Bősze 2011: 373), így a francia és magyar orvosi szaknyelvbe is. Az orvosi nyelv a többi tudományterület szaknyelvéhez hasonlóan folyamatosan új, angol eredetű terminusokkal bővül (Putz 2010: 370). A legkonzervatívabb orvosi területnek tartott tudományág, az anatómia szaknyelvében is felfedezhető az angol folyamatos térhódítása (Varga 2014: 41). Elemzésemet a latin és a görög (LG) terminusok vizsgálatán túl az angol eredetü terminusokra is 
kiterjesztem, hiszen nem kaphatunk teljes képet az adott szövegek jellemzőiről az idegen szavak tükrében, ha az elemzés nem számol be az angol eredetü terminusokról.

Nem meglepő tehát, hogy gyakran találkozunk magyar orvosi szövegekben göröglatin (pl.: krónikus, karcinóma, anatómia, hematoxilin) és angol (pl.: biopszia, skin-sparing mastectomia, graft) terminusokkal. Érdekes jelenség, amikor az idegen szavak más kifejezések tagjaként fordulnak elő, tehát például az angol, a magyar és a latin szavak egy fogalmon belül keverednek (pl.: laparoszkópos gastric band mütét, in-lay implantatio, diagnosztikus és staging laparoszkópia). Ilyenfajta hibrid kölcsönzésröl, egyesek által részforditásnak nevezett jelenségröl akkor beszélhetünk, ha az átadó nyelv legalább egy morfémáját közvetlenül átváltjuk (Lanstyák 2006: 26).

Ha szembe állítjuk egymással az idegen eredetủ és a nem idegen eredetű terminusokat, a tudományos terminusok és a köznyelvi szavak közötti különbségre gondolhatunk. Szinonimákként tekinthetünk a pulmonológus és a tüdőgyógyász szavakra, de ezek egyértelmüen más regiszterhez tartoznak. A pulmonológus idegen eredetű szakszó, terminus, míg a tüdőgyógyász lehet terminusértékü, de nem idegenszerü a nyelvközösség legtöbb tagja számára.

Ezt azért fontos tisztázni, mert a terminusokat szokás megkülönböztetni a köznyelvi szavaktól, de fontos leszögezni, hogy nincs éles határvonal a két fogalom között. Annál is inkább, mert lényegében bármely köznyelvi szó terminussá válhat egy adott beszédközösség számára, vagy akár egy adott szövegben is. A különbség a tudományos és a hétköznapi megismerés különbségeire vezethető vissza, hiszen a tudományos megismerési és megnevezési folyamat részletesebb, túlmegy a mindennapos megismerésen, és a valóság olyan szegletét osztályozza, amelyet a köznyelv egyáltalán nem, vagy csak kevésbé részletesen. A hétköznapi megismerés célja a gyakorlati hasznosság, míg a tudomány magyarázatot keres, pontosságra törekszik. A fö különbség, hogy a terminológia más szempont szerint osztályozza a valóságot, mindig a megismerö funkció kerül előtérbe, a megismerés túlmegy a hétköznapi tapasztalat körén. A köznyelvi szavak esetében a referenciális jelentés implicit, meghatározhatatlan, jelentős az egyéni variabilitás, jelentésük függ a kontextustól, fontos szerepet játszik a szinonímia és a poliszémia. Ezzel szemben a ter- 
minusok referenciális jelentése kidolgozott fogalomrendszerre vonatkozik, nem jellemzi egyéni variabilitás, adott szakterületen belül független a kontextustól, nem játszik jelentős szerepet a poliszémia, a szinonímia (Heltai 2004: 29).

Az orvosi szaknyelv terminusainak jelentős része idegen eredetü, de az orvos-beteg kommunikációban kiemelten fontos, hogy ezeknek a tudományos terminusoknak hatása van az olvasóra. Az eufemizmus neves kutatói (Tournier 1985, Demers 1991, Warren 1992) szerint például az idegen szavak eufemizáló jellegüek, megnehezítve ezzel az olvasó feldolgozási erőfeszítését. Fontos kérdés, hogy mennyire jellemző az angol forrásnyelvü szövegekre a tudományos terminusok szinonimákkal való helyettesítése, illetve, hogy milyen irányban változik ennek aránya a magyar és francia fordításokban (ha változik). A fordítók igyekeznek fordításaikat a célnyelvi olvasó igényeihez igazítani, ezért felmerül a kérdés, hogy ha ezek a terminusok eufemisztikus hatást keltenek, tehát elhomályosítják a jelölőt, hogy ne nevezzék meg a nemkívánatosnak ítélt referenst, akkor a fordító milyen tudatos vagy tudattalan stratégiákkal igyekszik a szóban forgó terminusokat megfeleltetni. A következő alfejezetben áttekintem az idegen szavak és a fordítás viszonyát.

\subsection{Idegen szavak a fordításban}

Ahogy azt az előző fejezetben bemutattam, az orvosi szaknyelv több diasztratikus változata ismert, de az érthetőség, a kommunikációs cél megvalósításának módja az orvos-laikus kommunikációban eltérö lehet az orvos-orvos kommunikációban tapasztaltakétól. Ez az eltérő regiszter eltérő terminológiát eredményez (Wright 2011: 246), amelynek egyik legjellemzőbb vonása a görög és latin terminusok eltérő eloszlása, valamint azok explicitációja, az orvostudományi terminus kerülése, körülírása, a regiszter ,lesüllyesztése” (Meyer és Mackintosh 2000).

Ahogy azt később bemutatom, az orvostudományi terminusok kerülésének stratégiája nemcsak interlingvális, de intralingvális fordításokban is megfigyelhető és kutatásra érdemes téma. Különösen érdekes akkor, ha a kommunikáció nyelvek és kultúrák közötti közvetítéssel, interlingvális fordítással egészül ki, hiszen különböző nyelvekben és kul- 
túrákban eltérő lehet az idegen szavak eloszlása, gyakorisága. Előfordul például, hogy a FNYSZ két terminust szinonimaként használ, a fordítónak pedig meg kell győződnie arról, hogy terminológiai szinonímiáról van szó (Heltai 2004: 39-41).

Lehetséges, hogy egyes orvosi LG terminusok az orvos-laikus kommunikációban sem okoznak jelentős feldolgozási erőfeszítést angolul vagy franciául, magyarul azonban túl magas regiszterre utalnának (pl.: appendicitis 'vakbélgyulladás'). LG terminusok gyakran fordulnak elő orvosi szövegekben, de nyelvekként eltérö lehet a terminusok gyakorisága, illetve az LG terminusok vernakuláris változatainak száma egyik vagy másik nyelven. Sokszor elöfordul, hogy az angol és a francia LG terminust használ olyan helyen, ahol a magyar nyelv kerüli az LG terminus használatát a laikusoknak szánt szövegekben, hiszen a latin és görög elemek nem gyakoriak ebben a nyelvben. Ez föként azzal magyarázható, hogy a nemzeti orvosi nyelvek történetében lényeges különbségek észlelhetők a terminológiai jellemzőkben. A francia, angol dermatologiste, dermatologist helyes megfelelője ilyen esetekben a bőrgyógyász.

Újlatin nyelveken tehát alacsony regiszterünek tünhet egy-egy olyan terminus, amely jól megállja a helyét angol tudományos szövegekben (Montalt Resurrecció és González Davies 2007: 242). A fordításban ilyenkor felmerül az orvostudományi terminus kerülése (determinologization), az átalakítás (reformulation) és az explicitáció lehetósége (Jiménez-Crespo és Tercedor Sánchez 2017: 407). A következő alfejezetben áttekintem a jelen tanulmány szempontjából releváns, korábbi kutatások eredményeit.

\subsection{Korábbi kutatások eredményei}

Muñoz-Miquel (2012) intralingvális fordításon végzett a jelen tanulmány szempontjából releváns vizsgálatot. Korpuszát tíz darab angol nyelvű, laikusoknak szóló összefoglalóból állította össze. A tudományos összefoglalókat orvosok által orvosoknak írt cikkek alapján tömörítették, fogalmazták át. Az intralingvális fordítás során a szelekciós folyamat része, hogy eltávolítsuk a szöveg olvasója szempontjából irrelevánsnak vagy túl nehéznek tartott tartalmakat. Gyakori, hogy hozzáadunk releváns, fontos információkat a kulcsfo- 
galmakhoz, hogy az olvasó számára a szöveg explicitebb, érthetőbb legyen, hiszen az olvasó és a szöveg írója feltehetőleg eltérő ismeretekkel rendelkeznek. Az elemzés szerint ez a stratégia leginkább a szövegek elején jellemző. A korpusz intralingvális fordításaiban a következőképpen jártak el az összefoglalások írói a tudományos terminusok esetén (Muñoz-Miquel 2012: 200-202):

- a tudományos terminus változatlan marad, de magyarázat vagy definíció van a terminus előtt vagy után (általánosságban a magyarázat zárójelben van, és megelőzi a terminust, de ez nem törvényszerü):

(1) More recently, researchers have suggested using tadalafil (a medicine often used to treat erectile dysfunction),

- a terminust idézőjelbe tett köznyelvi szinonima kíséri:

(2) herpes zoster (also called "shingles"),

- az eredeti szövegben nem szereplő egységeket vezetnek be az olvasó segítésének céljából (ez akár a -like szócska is lehet, pl.: cortisone-like drug known as dexamethasone)

(3) People commonly use nonsteroidal anti-inflammatory drugs (NSAIDs) to relieve pain. Examples of NSAIDs include aspirin, etodolac (Lodine), ibuprofen (Advil or Motrin), and naproxen (Aleve).

- a tudományos terminus kiesik, és egy kollokviálisabb „pszeudo-ekvivalens” helyettesíti:

(4a) myocardial infarction,

(4b) heart attack,

- perifrázis használata:

(5a) second-line treatment options, 
(5b) options for other drugs they could take,

- változás a mondathosszban és a morfoszintaktikai szerkezetben:

(6a) Study personnel who reconstituted the vials and inoculated the participants,

(6b) Staff injecting the solution under the skin.

Az elemzés rámutat, hogy a legtöbb esetben megőrizzük a tudományos terminusokat, de gyakran zárójelben, idézőjelben szereplő magyarázatokkal, szinonimákkal konkretizáljuk őket. Időnként előfordul, hogy a tudományos terminust pszeudo-ekvivalensekkel, perifrázisokkal helyettesítjük. Az elvont, absztrakt fogalmakat átfogalmazzuk, konkretizáljuk. A redundanciát növelve az összetett fogalmakat ismételjük, szinonimákat használunk. A szerző fontos és hasznos felosztást ad az idegen szavak lehetséges intralingvális átalakítási eljárásairól (reformulation procedures), de a különböző eljárások gyakoriságát nem számszerüsíti. Ahogy a tanulmány végén pontosítja, a korpusz kis méretü, és szövegei egy forrásból származnak, ezért további vizsgálatok szükségesek az eredmények alátámasztására. A tanulmány rámutat, hogy a stratégiák megfigyelése és leírása fontos feladat a további kutatásokban (Muñoz-Miquel 2012: 204). Figyelemre méltó, hogy az LG terminusok fordítására még intralingvális fordításon belül is van kutatási igény. Bár a bemutatott vizsgálat nem biztosít összehasonlíthatóságot az eredmények számszerüsítésének hiánya miatt, megerősíti a témában folyó kutatások fontosságát, és érdekes, hasznos, a jelen tanulmányban is felhasználható felosztást javasol az LG terminusok fordítási stratégiáinak leírására.

Zethsen (2004: 126) az angolról dánra fordított, laikusoknak szánt orvosi fordítások feldolgozási erőfeszítését rendkívül nehéznek tartja, hiszen a célnyelvi olvasó szakismeretek hiányában nem tudja, vagy nehezen tudja értelmezni a latin terminológia direkt átvitelét a fordításokban. A dán nyelvközösség számára vagy érthetetlen, vagy túl szakszerü egy-egy latin eredetü terminus, de egy átlagos angol beszélő számára semmiféle problémát nem okoz annak feldolgozása. Éppen ezért, ha figyelembe vesszük a fordítás szkoposzát, akkor sok esetben a latin terminusok direkt átvitele nem eredményez ek- 
vivalencia-viszonyt a forrásnyelv és a célnyelv latin eredetü terminusa között (Zethsen 2004: 138), mert az angol és a dán laikus olvasók ismeretei eltérők az idegen eredetü szavak tekintetében, az egyes idegen eredetü terminusok a két nyelvben más regiszterhez tartoznak. Ez azzal magyarázható, hogy az angol és a dán köznyelvben alapvetően eltér a latin és görög eredetű szavak gyakorisága. Ahogy a magyarról is elmondható, az angolhoz képest a dán is kevesebb LG terminust használ a mindennapi nyelvhasználatban, és ha az angolról dánra történő fordításban az LG terminusokat magyarázat vagy köznyelvi megfelelő betoldása nélkül átváltjuk, a fordított szöveg nehézsége drámaian növekszik.

Mindezt Nisbeth Jensen és Zethsen (2012) évekkel későbbi kutatása is alátámasztja, ahol az LG terminusok eloszlását angol és dán nyelvü szövegekben hasonlítják össze. Vizsgálatukban különösen fontos, hogy az LG terminusok fordítását tipizálják: két fő kategóriát és számos alkategóriát különböztetnek meg (dán nyelvismeret hiányában a példák ismertetésétől eltekintek):

- laikusokat segítő megoldások (lay-friendly option):

○ köznyelvi szó használata LG terminus helyett,

○ a sorrend változtatása: a dán terminus megelőzi az eredeti szövegben is szereplö LG terminust,

- laikusok igényéhez igazodó magyarázat vagy terminus betoldása az LG terminus megtartásával,

- laikusokat nem segítő megoldások (non-lay-friendly option):

○ ha az adott LG terminusnak nincs köznyelvi megfelelője, a fordító átváltja a forrásnyelvi LG terminust, és nem füz hozzá magyarázatot [pl.: polycystic ovarian syndrome (PCOS)],

○ a forrásnyelvi LG terminus és a köznyelvi szó vagy magyarázat fordítása változtatás nélkül, 
○ a fordító megtartja az LG terminust, pedig létezik köznyelvi dán megfelelő is,

○ a fordító betold LG terminust, pedig létezik köznyelvi dán megfelelő is.

A kutatók azt vizsgálták, hogy az LG terminusok tekintetében milyen különbségek és hasonlóságok írhatók le attól függően, hogy egészségügyi szakemberek, vagy profi fordítók tollából származik a fordítás. Az eredmények azt mutatják, hogy az egészségügyi szakemberek több LG terminust használnak a fordításban, és az is gyakoribb, hogy nem füznek hozzá magyarázatot. Akkor is hajlamosak LG terminust használni, ha van köznyelvi dán megfelelő. Jelen tanulmány nem tesz különbséget az egészségügyi szakemberek és a (szak)fordítók által fordított szövegek között, hiszen az elemzett szövegek mindegyike mindenki számára elérhető: az adott egészségügyi intézmény által publikált, a fordítók által lefordított és a megrendelő által elfogadott, betegek számára elérhető dokumentumok. Érdekesnek tartom azonban a laikusokat segítő és nem segítő felosztást, illetve a kutató által bemutatott stratégiákat.

Montalt Resurrecció és González Davies (2007: 251-253) szerint a tudományos terminus kerülésének az orvosi szaknyelvben négy alkategóriája különíthető el. A négy alkategória akár egyszerre is megvalósulhat:

- a célnyelven megmarad a tudományos terminus, de magyarázat követi

(7a) most dyskinesias are due to basal ganglia disorders...

(7b) most $d y$ skinesias (impairment of voluntary movements resulting in fragmented or jerky motions) are due to basal ganglia disorders...

- a célnyelven megmarad a tudományos terminus, de csak zárójelben szerepel

(8a) Rigidity progresses, and bradykinesia, hypokinesia, and akinesia appear. 
(8b) Rigidity progresses, and movements becomes slow (bradykinesia), decreased (hypokinesia), and difficult to initiate (akinesia).

- a tudományos terminust köznyelvi szóval helyettesítjük

(9a) Large haemorrhages, when located in the hemispheres, produces hemiparesis.

(9b) Intense bleeding, when located in the hemispheres, produces paralysis on one side of the body.

- a tudományos terminusokat teljesen kerüljük, és magyarázattal helyettesítjük

(10a) Most dyskinesias are due to basal ganglia disorders...

(10b) most impairment of voluntary movements is due to basal ganglia disorders...

Ezek a stratégiák könnyebben értelmezhetővé teszik a fordított szövegeket a laikus olvasó számára. Közülük az explicitáció, az a fordítási művelet, amelynek során a fordító nyíltabban, világosabban, esetleg több szóval fejez ki valamit a CNYSZ-ben, mint ahogy azt a FNYSZ szerzője tette (Klaudy 2001: 371). Ezen a ponton kell megjegyezni, hogy az explicitáció önmagában jellemző a fordított szövegekre, valamint az orvos és laikus közötti kommunikációra.

Jiménez-Crespo és Tercedor Sánchez (2017: 421) szerint a fordítási univerzálék újra tanulmányozása szakszövegen, sajátos müfajokon, regisztereken fontos feladat, hiszen az adott nyelvkombináció, regiszter és müfaj tükrében különbségeket állapíthatunk meg az eredmények alapján. A szerzők az összehasonlítható korpusznyelvészet módszertanával 40 millió szövegszavas korpuszt tanulmányoztak: angolról spanyolra fordított, illetve eredetileg spanyolul írt, betegeknek szóló internetes oldalakat vizsgáltak. A VariMed adatbázisból véletlenszerủen tizenhárom LG terminust választottak ki. A tanulmány rávilágít, hogy az LG terminusok átfogalmazási stratégiáinak (reformulation strategies) lehetősége szélesebb körü, mint ahogy az az adatbázisban szerepel, és vannak, amelyek 
közül néhány kizárólag fordított szövegekben azonosítható. Ez lehet interferencia eredménye, vagy a lexikalizált forrásnyelvi elemek szó szerinti átváltása.

A WordSmith Tools 6.0 segítségével a korpuszon mindegyik LG terminus relatív gyakoriságát mérték. Az elemzés második részében azt vizsgálták, hogy a weboldalak írói mennyire tartják szem elött a laikus olvasó igényeit (lay-friendliness): mennyire és milyen formában jellemző az LG terminusok átfogalmazása, a determinologizálás Montalt Resurrecció és González Davies (2007) korábban bemutatott terminuskerülési stratégiáinak tükrében. Az elemzés második részét manuálisan végezték a WordSmith Tools 6.0 konkordancia mezőinek vizsgálatával, az előfordulást normalizálták.

A vizsgálat eredményei kimutatták, hogy a két alkorpuszt összehasonlítva több LG terminus azonosítható az autentikus spanyol szövegekben, mint a fordított spanyol szövegekben. A fordított szövegben lévő LG terminusok alacsony hányada ellentmond az angol-dán nyelvpár esetében végzett kutatás eredményeinek (Nisbeth Jensen és Zethsen 2012), ahol az LG terminusok direkt átvitele érthetetlenné tette a dán szöveget a laikus célközönség számára. Ezzel szemben a laikusoknak szánt spanyol orvosi dokumentumokban gyakrabban szerepelnek LG terminusok, mint az autentikus angol szövegekben. Az eredmények szerint a fordításokban gyakrabban figyelhető meg átfogalmazás, explicitáció, mint az autentikus szövegekben, mert a FNYSZ szerzője determinologizációra törekszik, hogy könnyítse az angol nyelvü olvasó szövegértését, és a fordító is igyekszik a célközönség igényeit figyelembe véve az LG terminusokat explicitálni, átfogalmazni.

Elméleti síkon több szempontból is megközelíthető, hogy pontosan mi történik a fordítás folyamatában az idegen nyelvü szavakkal, kifejezésekkel. Ha a spanyol fordításokban kevesebb idegen eredetü terminus szerepel, mint az autentikus spanyol szövegben, akkor a fordító Baker (1996) terminusával élve normalizációra törekszik, a célnyelv jellemzőit igyekszik kiemelni. Kenny (1998: 516) ezt úgy közelíti meg, hogy a fordító igyekszik minél jobban adaptálni a CNYSZ-et a célközönség igényeihez, ezért a fordítás eredményeképpen keletkezett szöveget „megtisztítja” (sanitisation), hogy elfogadhatóbbá tegye azt a célnyelvi olvasó számára. Előfordul, hogy az eredeti szöveget összehasonlítva a fordítással úgy érezzük, hogy a fordítás eltompítja a FNY-i szöveg esetleges ridegségét, 
negatív töltetét. A fordításban tehát semlegesebb elemek jelenhetnek meg a forrásnyelv negatív szemantikai prozódiájú elemeinek megfeleltetésekor, és bár nehéz rájönni, hogy mitől válik a CNYSZ mássá, a végleges hatás az, hogy a fordítás az eredeti „megtisztított” változata lesz. Kenny (1998) szerint érdemes lenne lexikai elemek szemantikai prozódiájának mérése FNYSZ-en és fordításokon, ehhez szükség lenne párhuzamos, illetve forrásnyelvi és célnyelvi referenciakorpuszra. A tanulmányában hozott példák nem reprezentatívak, de érdekes empirikus kutatási irányokat vetnek fel, és rámutatnak a párhuzamos és egynyelvü összehasonlítható korpuszok használatának fontosságára.

Az idegen szavak hatását megközelíthetjük az eufemizmus jelenségén keresztül is, ahogy arra korábban utaltam. Egy kommunikációs helyzet akármelyik résztvevője akármikor érezheti úgy, hogy mondandóját szépíteni, enyhíteni kell. Mindez függ egyrészt attól, hogy az adott korszak társadalmi, kulturális és nyelvi normái milyen fogalomkörök esetében sugallják, hogy a szavak élét tompítani kellene. Ugyanakkor egy egyén által eufemisztikusnak ítélt egységet nem feltétlenül tart annak egy másik is: az eufemizmus tanulmányozása, elemzése tehát sosem lehet teljesen mentes a szubjektivitástól, de szubjektív jellege ellenére is levonhatók általános következtetések, megfogalmazhatók objektív jellegzetességek. Az eufemizmus elhomályosítja a jelölőt, mert lehetővé válik, hogy az információ közlője ne nevezze meg a nemkívánatosnak ítélt referenst, de maga a referens valójában változatlan. Az eufemizmus során tehát nem a fogalom vagy a jelölt változik, hanem maga a nyelvi jel. Voltaképpen egy olyan új nyelvi jelről van szó, amely egy másik nyelvi jel elhomályosított változata. A jelölttel és a fogalommal azonban ugyanolyan kapcsolata van. Az eufemizmus tanulmányozásának kérdése tehát az, hogy milyen kapcsolat van az eufemisztikus nyelvi jel és a diszfemisztikus nyelvi jel között (Jamet 2010: 35). Mindezt azért tartom relevánsnak, mert az eufemizmus több kutatója (Tournier 1985, Demers 1991, Warren 1992) szerint az idegen szavaknak, terminusoknak eufemisztikus hatása van.

A kutatás célja az idegen szavak azonosítása, gyakoriságuk és a fordítási stratégiák kimutatása és leírása angolról magyarra és franciára fordított betegtájékoztatókban, a különbségek és hasonlóságok megfigyelése a különböző nyelvű szövegek között, a lehet- 
séges eltolódások kimutatása a fordított szövegekben. Mindez rámutatna az orvosi szövegek fordításának mindeddig kevéssé kutatott jellegzetességeire, általánosíthatóságaira. A tanulságokat alkalmazni lehetne az orvosi szakfordítók munkájában, képzésében, illetve össze lehetne hasonlítani korábban végzett kutatások eredményeivel.

\section{Módszerek}

Két okból választottam elemzésem tárgyaként az orvosi szaknyelv egyik sajátos müfaját, a betegtájékoztatót az idegen szavak vizsgálatára. Az első, hogy a gyógyszerészeti, terápiás és orvosi kísérőiratok nyelvészeti elemzése a nyelvtudomány számára egyelöre feltáratlan terület (Illésné Kovács és Simigné Fenyő 2009: 141), annak ellenére, hogy napjainkban az egészségügyi felvilágosító irodalom a legolvasottabb szövegtípusok egyike (Tótfalusi 2008: 12). Fontosnak tartom, hogy a betegtájékoztató néven ismert müfajon kívül nem vonok be más müfajú orvosi dokumentumot a vizsgálatba, mert az eredmények müfajonként eltérök lehetnek (Jiménez-Crespo és Tercedor Sánchez 2017: 412). A müfaj angol nyelvü elnevezései: patient information leaflet (PIL), package insert, information leaflet, patient package insert, consumer medicine information (Montalt Resurrecció és González Davies 2007: 68).

\subsection{A korpusz}

Az orvosi szaknyelv egyik diasztratikus változatának tekintem az orvos-laikus kommunikációt. Az orvosi szaknyelv szakember és laikusok közötti nyelvhasználati rétegének jellemzője, hogy a kommunikáció résztvevői eltérő szakmai ismeretekkel rendelkeznek (Kurtán 2003: 33). A sikeres kommunikáció megvalósításához szükséges, hogy az orvosi szövegeket a szöveg szerzője és fordítója a laikus befogadó elvárásaihoz adaptálja. Az orvosi szakfordító fontos feladata, hogy az általa használt regiszter illeszkedjen a célközönség igényeihez (Jiménez-Crespo és Tercedor Sánchez 2017: 406), az autentikus és fordított szövegek regiszterbeli különbségének egyik legfontosabb alkotóeleme pedig az LG terminusok eloszlása, explicitációja vagy terminuskerülése, átfogalmazása (Meyer és 
Mackintosh 2000). Éppen ezért a müfaj kiválasztására motiváló második ok, hogy ezek a közvetett, írott formájú, betegeknek és hozzátartozóiknak készített tájékoztatók jó lehetöséget adnak annak feltárására, hogy az idegen szavak milyen mennyiségben és formában (pl.: tudományos terminus kihagyása, körülírása, helyettesítése stb.) jelennek meg az eredetileg angolul írott betegtájékoztatókban és a magyar, francia fordításokban.

Az összegyüjtött szövegekre párhuzamos korpuszként (Baker 1993) tekintek, hiszen a korpusz angol nyelvű szövegeket és azok francia és magyar fordításait tartalmazza. Ezek a szövegek elérhetök a Pannónia Korpusz (Robin et al 2016) folyamatosan épülö orvosi alkorpuszában. A párhuzamos korpusz elemzése lehetővé teszi annak feltárását, hogy az eltolódások oka intralingvisztikai vagy interlingvisztikai explicitációban keresendö-e (Jiménez-Crespo és Tercedor Sánchez 2017: 420). A párhuzamos korpuszok hozzájárulnak, hogy az empirikus kutatások a leíró fordítástudományt szolgálják, és rávilágítanak arra, hogyan oldják meg a fordítók az egyes fordítási problémákat (Robin et al 2016), hogy milyen különbségek vannak az eredeti és a fordított szövegek között (Seidl-Péch 2018), tehát milyen tudatos vagy tudatalatti stratégiákat alkalmaz a fordító az LGA terminusok fordításakor. A párhuzamos korpusz rámutat a fordító müveleteire, stratégiáira, illetve azt is megmagyarázza, hogy miként befolyásolja a fordító megfogalmazását az eredeti FNYSZ.

Az elemzésben három alkorpuszt vizsgálok: autentikus angol, fordított magyar és fordított francia szövegeket. Mindegyik szöveg 2000 után született. A reprezentativitás szempontjából fontos, hogy a korpusz több szerző és fordító munkájából tevődik össze (Robin et al 2016).

Tematikájukat tekintve a szövegek egy része gyermeket vállaló szülőknek szól az esetleges genetikai betegségekről, illetve azok öröklődéséről, vizsgálatáról. A korpusz többi szövege a myeloma multiplex nevű rosszindulatú betegség kezeléséről, az őssejtterápiáról, szívelégtelenségről szól, illetve mütét előtti tájékoztató.

Az elemzéshez használt angol forrásnyelvü betegtájékoztatók, illetve azok francia és magyar fordításának terjedelmét, szószámát az 1. táblázat foglalja össze. A kor- 
pusz összesen 87577 szövegszóból áll. Az angol forrásnyelvi alkorpusz mérete összesen 28492 szövegszó, a francia fordítás összesen 33301 szövegszóból áll, míg a magyar 25784 szövegszóból. A fordított magyar és a fordított francia alkorpuszok közötti terjedelmi különbség azért nem befolyásolja a vizsgálat eredményeit, mert mindkét célnyelvi alkorpusz ugyanannak az angol forrásnyelvi alkorpusznak a fordítása.

\section{1. táblázat}

A párhuzamos korpusz szószáma

\begin{tabular}{|l|c|c|c|}
\hline \multicolumn{1}{|c|}{ A betegtájékoztató angol címe } & $\begin{array}{c}\text { Az angol } \\
\text { FNYSZ ter- } \\
\text { jedelme (szó- } \\
\text { Szám) }\end{array}$ & $\begin{array}{c}\text { A magyar } \\
\text { CNYSZ ter- } \\
\text { jedelme (szó- } \\
\text { Szám) }\end{array}$ & $\begin{array}{c}\text { A francia } \\
\text { CNYSZ ter- } \\
\text { jedelme (szó- } \\
\text { Szám) }\end{array}$ \\
\hline The Amniocentesis & 1366 & 1149 & 1360 \\
\hline Dominant Inheritance & 925 & 959 & 1171 \\
\hline Recessive Inheritance & 978 & 896 & 1212 \\
\hline Frequently Asked Questions & 619 & 531 & 602 \\
\hline Stem Cell Therapies & 3340 & 2797 & 4171 \\
\hline Chromosome Translocations & 1401 & 1249 & 1537 \\
\hline What is a Genetic Test? & 1284 & 1156 & 1373 \\
\hline $\begin{array}{l}\text { Multiple Myeloma, Cancer of the Bone } \\
\text { Marrow }\end{array}$ & 13583 & 12394 & 16512 \\
\hline Carrier Testing & 3371 & 2367 & 3558 \\
\hline Chromosome Changes & 1625 & 2286 & 1805 \\
\hline Összesen & $\mathbf{2 8 4 9 2}$ & $\mathbf{2 5 7 8 4}$ & $\mathbf{3 3 3 0 1}$ \\
\hline
\end{tabular}

\subsection{Kutatási kérdések}

Ahogy azt korábban bemutattam, a jelen kutatás központi kérdése az idegen szavak elöfordulása angolról magyarra és franciára fordított betegtájékoztatókban. Az idegen szavak eredetét, gyakoriságát, az előfordulásukra jellemző hasonlóságokat és különbségeket, a fordítási stratégiákat a bemutatott korpusz alapján a következő konkrét kutatási kérdések vizsgálatával elemzem: 
(1) Milyen gyakorisággal fordulnak elö idegen szavak az autentikus angol és a fordított magyar és francia orvosi szövegekben?

(2) Milyen fordítási stratégiák azonosíthatók az idegen szavak fordításakor az adott nyelvek/nyelvpárok tükrében, hogyan alkalmazkodik a fordítói a laikusok célnyelvi olvasó igényeihez?

\subsection{Hipotézis}

A kutatási kérdések tekintetében a kutatás kvantitatív részére a következő hipotézis állítható fel:

Az angol autentikus szövegekben kevesebb LG terminus van, mint a fordított magyar és francia szövegekben a vizsgált nyelvek szókészletének különbségei miatt.

\subsection{Az elemzés menete}

Az elemzéshez elengedhetetlen, hogy a pdf, html és word formátumban letölthető fájlokat UTF-8 kódolású txt formátumba konvertáljuk, mivel az internetről ingyenesen letölthető és használható AntConc nevü program csak txt fájl importálására alkalmas. Az elemzés következő lépésében az AntConc 3.5.0. segítségével lehívtam a gyakorisági listákat. A kinyert szavakat Excel formátumú dokumentumba másoltam, és kitöröltem az egyértelmüen nem idegen eredetü szavakat, és kigyüjtöttem azokat, amelyek LGA terminusok lehetnek. Ennek a lépésnek köszönhetően kiszürhetők a magas gyakoriságú névelők, kötőszók, elöljárószók és az egyértelmúen köznyelvi szavak, amelyek kétséget kizáróan a mindennapos nyelvhasználathoz, a köznyelvhez tartoznak. Az elemzést lényegesen megkönnyíti, hogy kitörlöm azokat a szavakat, amelyek egyértelmủen nem idegen eredetüek (pl.: of, that, health, skin, family; az, Ön, egészség, családtag, vizsgálat; santé, mais, effet, corps). 
Az elemzés folytatásában elkülönítettem azokat a terminusokat, amelyek bizonyosan idegen eredetü egészségtudományi terminusok vagy részben idegen eredetü, hibrid terminusok részei (pl.: izomdisztrófia, össejttranszplantáció, sejtproliferáció). Ennek köszönhetően kinyertem azokat a terminusokat, amelyek kétségkívül a jelen elemzés tárgyát képezik. Ezt a lépést a 2. táblázattal szemléltetem.

\section{2. táblázat}

Egyértelmüen idegen eredetü terminusok kiválasztása

\begin{tabular}{|l|c|c|c|}
\hline \multicolumn{1}{|c|}{ A betegtájékoztató angol címe } & $\begin{array}{c}\text { Az angol FNYSZ } \\
\text { terjedelme } \\
\text { (szószám) }\end{array}$ & $\begin{array}{c}\text { A magyar } \\
\text { CNYSZ } \\
\text { terjedelme } \\
\text { (szószám) }\end{array}$ & $\begin{array}{c}\text { A francia } \\
\text { CNYSZ } \\
\text { terjedelme } \\
\text { (szószám) }\end{array}$ \\
\hline The Amniocentesis & 1366 & 1149 & 1360 \\
\hline Dominant Inheritance & 925 & 959 & 1171 \\
\hline Recessive Inheritance & 978 & 896 & 1212 \\
\hline Frequently Asked Questions & 619 & 531 & 602 \\
\hline Stem Cell Therapies & 3340 & 2797 & 4171 \\
\hline Chromosome Translocations & 1401 & 1249 & 1537 \\
\hline What is a Genetic Test? & 1284 & 1156 & 1373 \\
\hline $\begin{array}{l}\text { Multiple Myeloma, Cancer of the Bone } \\
\text { Marrow }\end{array}$ & 13583 & 12394 & 16512 \\
\hline Carrier Testing & 3371 & 2367 & 3558 \\
\hline Chromosome Changes & 1625 & 2286 & 1805 \\
\hline Összesen & 28492 & 25784 & 33301 \\
\hline
\end{tabular}

A további szelektálási folyamatot két tényező nehezítette meg. Egyrészt ahogy azt korábban bemutattam, nem vonható éles határvonal az idegen szavak és a jövevényszavak között. Szubjektív és akár egyénenként változó lehet, hogy az adott szót vagy terminust mennyire érezzük idegenítőnek. Másrészt úgy gondolom, hogy a szövegek elemzésekor akarva-akaratlanul hajlamosak lehetünk arra, hogy idegen szónak érzékeljünk olyan szavakat is, amelyeket egyébként talán nem tekintenénk annak. Az elemzés során érzékenyebbé, vagy éppen kevésbé érzékennyé válhatunk elemzésünk tárgyára. 
Úgy küszöböltem ki a szubjektív faktort, hogy segítségül hívtam az angolul, franciául és magyarul írt idegen szavak szótárát. Ahogy azt az elemzéshez használt magyar szótár szerzője kiemeli az előszóban, a szótárban nem szerepelnek a nyelvbe már teljesen beolvadt idegen elemek, ellenben külön hangsúlyt fektet a közhasználatba mindinkább átkerülő tudományos szakszókincsre (Bakos 2015: 4-5). Bár a szubjektív jelleg a szótárállományra is jellemző, az elemzés objektív, mivel a kérdéses terminusok meglétét ellenőrzöm az idegen szavak szótárában. Ha ezen kérdéses elemek idegenszerüsége az elterjedt köznyelvi használat miatt sem egyértelmü, de szerepelnek a szótárban (pl.: abnormális, kromoszóma, diagnosztika), akkor elfogadom ezt az álláspontot, és idegen eredetủ terminusként tekintek rájuk, tehát bevonom őket az elemzésbe. Ha egy terminus esetleges idegen csengése ellenére nem szerepel a szótárban (pl.: herpesz, bakteriális, monitorozás), akkor azt nem vonom be az elemzésbe.

Az elemzés tehát rávilágít, hogy milyen gyakorisággal fordulnak elö LGA terminusok az elemzett korpusz orvosi szövegeiben. Fontos azonban, hogy ne csak a gyakoriságot vizsgájuk, mert az AntConc nem szótővenként adja ki a találatokat, ezért a toldalékolt terminusok lentebb lesznek a listában, mint a toldalékolatlan változatok. Az elemzés folytatásában lemmatizálással azonosítottam az idegen szavak körében a típusokat a tokenekhez képest. Az AntConc segítségével lehívott gyakorisági listát Excel táblázatba másoltam, és a már bemutatott módszer segítségével kiszürtem az idegen eredetü terminusokat. Az LGA terminusok gyakoriságát az Excelben összeadtam, így megkaptam az egyes betegtájékoztatókra és az egyes nyelvekre jellemző LGA-gyakoriságot.

A folytatásban összehasonlítottam a LGA terminusok gyakoriságát az angolról magyarra és az angolról franciára fordított szövegekben, valamint az angol FNYSZ-ben. Így elözetes képet nyerünk arról, hogy a vizsgált nyelvek között milyen különbségek vannak az LGA terminusok gyakoriságának tükrében. A különbségek azonban fakadhatnak interferenciából is, ezért a fordított magyar alkorpusz eredményeit a kutatás folytatásában az autentikus magyar alkorpusz eredményeivel fogom összehasonlítani. Ennek köszönhetően adatot nyerhetünk arról, hogy gyakoribb-e az autentikus magyar szövegekben a LGA 
terminusok használata, mint az angolról magyarra fordított szövegekben, és további fordítói stratégiákra következtethetünk az adott müfaj és az adott nyelvkombináció tükrében.

Ezen a ponton tértem át a vizsgálat kvalitatív részére. Az elemzés következő lépésében a MemoQ szövegpárhuzamosító funkcióját használtam, amely lehetővé teszi, hogy megvizsgáljam adott terminusok környezetét. Ez azért fontos, mert arra számítottam, hogy a szerző bizonyos esetekben például zárójelben szerepelteti az LGA terminust, de a magyar fordító esetenként köznyelvi szót választott a forrásnyelvi LGA terminus megfeleltetésére. A párhuzamosítás azért is szükséges, mert nem biztos, hogy az LGA terminusokat a fordító megtartja, és szükséges megvizsgálnunk, hogy az adott angol szöveg idegen eredetü terminusa hogyan jelenik meg a magyar és a francia fordításban. A párhuzamosítással tehát kigyüjtöm az LGA terminusokra jellemző fordítási stratégiákat, majd beillesztem őket az elméleti háttérben bemutatott, korábbi kutatásokban javasolt stratégiák különböző kategóriáiba, vagy új kategóriákat állapítottam meg.

Elemzésemben továbbá arra törekedtem, hogy hasonlóságokat vagy különbségeket figyeljek meg az angolról franciára és magyarra fordítás stratégiájának tükrében az adott korpusz alapján. A tanulmány következő fejezetében rátérek a kutatási kérdések megválaszolására, a hipotézisem igazolására vagy elvetésére.

\section{Eredmények}

A jelen kutatás központi kérdése az idegen szavak jelensége, gyakorisága angolról magyarra és franciára fordított betegtájékoztatókban. Az eredmények tekintetében az első kutatási kérdésre vonatkozó adatokról számolok be.

\subsection{LGA terminusok az egyes alkorpuszokban}

Az angol FNYSZ-ekben mindösszesen 1374 idegen eredetü latin és görög terminust azonosítottam az Oxford Dictionnary of Foreign Words and Phrases (Speake 1997) szótár segítségével. Ez a szám az idegen szavak gyakorisági vizsgálatához felhasznált angol for- 
rásnyelvi alkorpusz teljes szószámának (28 492 szövegszó) 4,82\%-a. Az idegen szavak gyakorisági vizsgálatához használt fordított magyar nyelvü alkorpuszban (25 784 szövegszó) összesen 2182 idegen eredetü terminust azonosítottam, ami az alkorpusz teljes szószámának 8,46\%-a. A fordított francia alkorpusz (33 301 szövegszó) összesen 2005 idegen szót tartalmaz, ez az alkorpusz teljes szószámának 6,02\%-a. Megállapítható tehát, hogy a vizsgált korpusz alapján az angolra jellemző legkevésbé az idegen szavak használata. Az angolhoz képest több idegen szó azonosítható a francia alkorpuszban, és a legtöbb idegen szó a magyar alkorpuszban van. Ezt a tendenciát nem csak az egyes alkorpuszokat összehasonlítva figyelhetjük meg, hanem akkor is, ha az egyes betegtájékoztatókat egymással összehasonlítjuk. A számadatokat a 3. táblázat foglalja össze.

\section{3. táblázat}

A párhuzamos korpusz LGA terminusainak száma

\begin{tabular}{|l|r|r|r|}
\hline \multicolumn{1}{|c|}{ A betegtájékoztató angol címe } & $\begin{array}{c}\text { Idegen szavak az } \\
\text { autentikus angol } \\
\text { alkorpuszban } \\
\text { (szószám) }\end{array}$ & $\begin{array}{c}\text { Idegen szavak a } \\
\text { fordított magyar } \\
\text { alkorpuszban } \\
\text { (szószám) }\end{array}$ & $\begin{array}{c}\text { Idegen szavak a } \\
\text { fordított francia } \\
\text { alkorpuszban } \\
\text { (szószám) }\end{array}$ \\
\hline The Amniocentesis & 5 & 19 & 28 \\
\hline Dominant Inheritance & 11 & 45 & 21 \\
\hline Recessive Inheritance & 10 & 6 & 32 \\
\hline Frequently Asked Questions & 1 & 99 & 2 \\
\hline Stem Cell Therapies & 34 & 131 & 81 \\
\hline Chromosome Translocations & 56 & 30 & 106 \\
\hline What is a Genetic Test? & 17 & 1548 & 22 \\
\hline $\begin{array}{l}\text { Multiple Myeloma, Cancer of the Bone } \\
\text { Marrow }\end{array}$ & 144 & 122 & 495 \\
\hline Carrier Testing & 53 & 154 & 112 \\
\hline Chromosome Changes & 43 & & 122 \\
\hline
\end{tabular}

Ennek tekintetében igazolódott az (1) hipotézis, amelyben azt feltételeztem, hogy a fordított magyar és a fordított francia betegtájékoztatókban több az LGA terminusok száma, mint a hasonló terjedelmủ autentikus angol betegtájékoztatókban. Ez azzal magyaráz- 
ható, hogy a fordító igyekszik ezeket a terminusokat a laikus célközönség igényeihez igazítani, de a betegedukációnak mégis fontos része, hogy a betegek megismerkedjenek a betegséget jellemző, alapvető tudományos terminusokkal, hogy hatékonyan tudjanak kommunikálni az őket ápoló egészségügyi szakszemélyzettel. Az eredmények oka továbbá abban rejlik, hogy a magyar köznyelven alapvetően kevesebb a latin és görög eredetü terminusok aránya, mint az angolban vagy a franciában, ezért a magyar nyelvü célközönség idegenítőnek érez olyan LGA terminusokat, amelyek az angolban a köznyelvi beszélö számára ismertek, nem okoznak megnövekedett feldolgozási erőfeszítést. Ugyancsak fontos megjegyezni, hogy az angol és a francia betegtájékoztatókban azonosított angol eredetü terminusok értelemszerủen nem hatnak idegenszerüen az angol FNYSZ-ben, de a francia és a magyar fordításokban igen. Felmerül továbbá a kérdés, hogy az elemzéshez használt szótárak között milyen különbségek lehetnek, hogy a különböző nyelvek idegen szavainak szótárai azonos rendszerező elvet használnak-e. Utóbbi módszertani kérdést úgy fogom megválaszolni, hogy a jövőben angol, francia és magyar anyanyelvi beszélőkkel végeztetek hatásvizsgálatot.

A számszerü eredményekből továbbá az a következtetés vonható le, hogy a fent felsorolt okok miatt a célnyelven megnövekedett idegen szavak száma miatt az adott nyelvközösség számára a magyar és a francia szöveg idegenszerübben hat, mint az angol FNYSZ. Mindez felveti a kérdést, hogy a fordító milyen stratégiákkal igyekszik kielégíteni a laikus célnyelvi olvasó igényeit, hogy mit tesz, hogy csökkentse az idegen szavakkal találkozó olvasó feldolgozási erőfeszítését. Ennek megválaszolásához azt is fontos megállapítani, hogy milyen különbségek vannak az idegen szavak gyakoriságának tekintetében autentikus magyar és fordított magyar szövegek között. Erre egy másik kutatásban vállalkozom.

\subsection{Az LGA terminusokra jellemző fordítási stratégiák}

Felmerül tehát a kérdés, hogy milyen stratégiákkal törekszik a fordító kielégíteni a laikus célközönség igényeit? Milyen szövegkörnyezetben figyelhető meg, hogy a fordító megtartja a forrásnyelvben is fellelhető idegen szavakat? 
A kérdés megválaszolásához szükséges áttérnünk a kutatás további kérdéseire, a betegtájékoztatók fordítási stratégiáira, bár a kvantifikált eredmények tükrében arra lehet következtetni, hogy bizonyos esetekben a fordító az idegen szavak mellé magyarázatokat told be. A fordítási stratégiák elemzéséhez vegyük példaként a mielómáról szóló angol betegtájékoztató leggyakrabban előforduló terminusát. A myeloma terminus (244), annak többesszámú alakja myelomas (1), és terminológiai szinonimája $M M$ (4) a legtöbbször előforduló terminus az angol forrásnyelvü tájékoztatóban. A magyar fordítás elemzésénél gondosan ügyelnünk kell arra, hogy a találati listát ábécé sorrendbe állítsuk a gyakorisági lista lehívása után. Ez azért fontos, mert az AntConc nem szótővenként adja ki a találatokat, ezért a toldalékolt terminusok lentebb lesznek a listában, mint a toldalékolatlan változatok. Nem meglepő, hogy a mielóma terminus és annak toldalékolt vagy szóösszevonással keletkezett változatai adják a magyar célnyelvi korpusz leggyakrabban előforduló (269) idegen eredetü terminusát. Ebből az adatból látható, hogy a magyar fordítás ebben az esetben is többször szerepelteti az adott idegen szót, mint az angol FNYSZ. Itt feltehetőleg arról van szó, hogy ahol az angol időnként névmással utal vissza a betegség megnevezésére, vagy ahol a többszörösen összetett mondatokban nem szükséges a betegség nevét többször említeni, a magyar fordító a könnyebb érthetőséget szem előtt tartva a fönevet használja.

Ezen a ponton merül fel a kérdés, hogy a fordító milyen stratégiákkal igyekszik alkalmazkodni a célnyelvi olvasó, a laikus befogadó igényeihez. A mielóma multiplex a csontvelő daganatos megbetegedése, ahogy az a tájékoztatóból is kiderül. A fordító ebben az esetben nem laikusbarát megoldást (non-lay-friendly option) választott (Nisbeth Jensen és Zethsen 2012 terminusa), ha a meglévő köznyelvi szinonima helyett a tudományos terminust választotta, aminek több oka is van.

Először is a fordítónak nemcsak a célnyelvi olvasóhoz kell igazodnia, hanem meg kell találnia az arany középutat a befogadó, de az őket gondozó egészségügyi szakszemélyzet és a FNYSZ-et író tudósok elvárásai között. A mielóma multiplex a betegség hivatalos elnevezése a Betegségek Nemzetközi Osztályozásában (BNO). Nem várhatjuk az orvosi szaknyelvektől, hogy mellőzzék az alapjaiban LGA gyökereken nyugvó termin- 
ológiájukat, és nem helyettesíthetünk mindent tudományos terminust köznyelvi szóval. A leukémia helyett sem használhatjuk orvosi szövegekben a közérthető fehérvérüség szót, és nem mondhatjuk egy betegnek, hogy menjen a vesegyógyászatra, ha az adott osztály hivatalos neve nefrológia.

A másik ok a fordítás folyamatában rejlik. A tanulmányban azt vizsgálom, hogy hogyan változnak, vagy maradnak változatlanok az idegen eredetü terminusok a fordítás folyamatában. De vajon hol kezdődik a fordítás folyamata? Ott, amikor a magyar vagy francia fordító kézbe veszi az angol FNYSZ-et? Ebben az esetben nem lehet szó erről, hiszen a betegtájékoztatók műfaji sajátosságaiból fakad, hogy már a FNYSZ keletkezését is feltételezhetjük intralingvális fordítás eredményének. Ezt a feltételezést a következö, a korpuszomban szereplő betegtájékoztatóból vett idézettel támasztom alá:

Tájékoztató a gyulladásos betegeknek. A kérdéseket nemzetközileg vizsgált, az érintett betegek által felvetett problémák alapján állitottuk össze. A válaszokban a The Crohn's and Colitis Foundation of America, az Europien Crohn and Colitis Organisation és a Magyar Gasztroenterológiai Társaság Colon Szekciójának állásfoglalásait összegeztük. (Lakatos et al. 2005: fedőlap)

Ahogy az idézetből is kitünik, ebben az esetben három különböző szakmai szervezet képviselői a laikus betegekben felmerülő kérdésekre válaszolva dolgozták ki a betegtájékoztatót. Az orvosi szaknyelv szakember és laikusok közötti nyelvhasználati rétegének jellemzője, hogy a kommunikáció résztvevői eltérő szakmai ismeretekkel rendelkeznek (Kurtán 2003: 33), ezért feltételezhető, hogy az anyag kiadása előtti megbeszéléseken, konzultációkon a szakemberek kommunikációjára más terminushasználat volt jellemzö, mint amilyen az a kiadott anyagban azonosítható. Éppen ezért gondolom, hogy a fordítás folyamata valójában ott kezdődik, amikor az egészségügyi szakemberek közérthető módon igyekeznek megfogalmazni valamit laikusok számára az anyanyelvükön. Mindennek nyomai az autentikus és a fordított szövegeken is azonosíthatók. Az autentikus angol lai- 
kusoknak szóló szövegben tehát alapvetően kevesebb LG terminus van, mint egy autentikus angol, nem laikusoknak szóló klinikai kutatásban.

Fontos feladat a terminusok lexikai környezetének vizsgálata, kiemelt figyelmet fordítva a terminus első előfordulására, hiszen Muñoz-Miquel (2012: 200-202) kutatása rávilágít, hogy leginkább a szöveg elején igyekszünk az olvasó szempontjából túl nehéznek ítélt terminus magyarázatára, explicitálására, illetve releváns információk hozzáadására, amelyek szintén tartalmazhatnak idegen szavakat, terminusokat. Ugyancsak a szöveg elején azonosított terminusokra a legjellemzőbb intralingvális fordítási stratégia, amikor a tudományos terminus változatlan marad, de magyarázat vagy definíció van a terminus előtt vagy után.

Betegtájékoztatók vizsgálatakor számos esetben már maga a cím is rávilágít arra, hogy a tudományos terminusokat már a forrásnyelven is igyekeznek definiálni, magyarázatokkal kísérni. A következő példák az elemzés párhuzamos korpuszában elemzett tájékoztató címe és annak magyar és francia fordításai.

(11a) Multiple myloma, cancer of the bone marrow

(11b) Mielóma multiplex, a csontvelö daganatos betegsége

(11c) Myélome multiple, cancer de la moelle osseuse

Egyértelmü, hogy az orvos-orvos kommunikációban a betegség köznyelvi megfelelöjére nincsen szükség. Ha az angol címre intralingvális fordításként tekintünk, akkor a magyarázatra (cancer of the bone marrow) a szerző által végrehajtott tudatos betoldásként, explicitációként tekinthetünk. A magyar és a francia fordításokban megfigyelhető a betegség magyarázatának átváltása (a csontvelö daganatos betegsége, cancer de la moelle osseuse), a fordító nem vett el és nem adott hozzá a forrásnyelv címéhez. Azt gondolom azonban, hogy a fordító részéről éppen olyan tudatosság figyelhető meg, mint amilyen a szerző részéről, amikor megadja a tudományos terminusok közérthető magyarázatát. Az 
orvos-laikus kommunikáció az orvosi szaknyelv egyik diasztratikus változata, és természetes, hogy az orvosi szaknyelvben (ellentétben például a szépirodalmi szövegekkel vagy a sajtószövegekkel) jelentős számú tudományos terminus azonosítható. Nem ritka, hogy a betegtájékoztatók végén külön fejezetet szánnak az adott témában releváns fogalmak tisztázására, meghatározására, ahogy az a korpusz több betegtájékoztatójában is látható (pl.: Multiple myeloma, cancer of the bone marrow; What is a genetic test?). A terminusok magyarázó jellegü, laikusok számára érthető tisztázása során ugyancsak felmerülhetnek idegen szavak, növelve ezzel a CNYSZ idegen eredetű terminusainak számát. Ebben a fordítási stratégiában az idegen szavak száma nem nő a fordításokban, de nem is csökken. Megjegyzendő azonban, hogy már ennél a stratégiánál is felmerül, hogy egy betegség tudományos megnevezése is lehet idegenítő a magyar olvasó számára úgy, hogy az angol laikus olvasó az angol terminust ismeri.

Úgy gondolom, hogy a betegtájékoztatók nyelvészeti elemzéséről szóló tanulmányokból kiemelt idézetek rámutatnak arra, hogy a laikusoknak szánt orvosi dokumentumokban fellelhető idegen szavak használata természetes, magától értetődő.

A szituáció sajátosságai következtében ez egyirányú kommunikáció, azaz információközlés, melynek során nincs mód a visszacsatolásra, a dekódolás nem kontrollálható. Ezért a szövegszerkesztés során kell olyan elemeket [...] alkalmazni, amelyek megkönnyitik a laikusok számára íródott, de a szakszöveg elemeit is tartalmazó információ megértését, lehetővé teszik, hogy a beteg valóban megértse az instrukciókat és azoknak megfelelően járjon el. (Illésné Kovács és Simigné Fenyő 2008: 168).

Szó sincs tehát arról, hogy az idegen szavakat mellőzni kellene laikusnak szánt orvosi iratok szerkesztésekor vagy fordításakor. A lényeg, hogy betegtájékoztatók esetén „a kommunikáció sikere [...] a mondanivaló közérthetőségének, a szakkifejezések világos használatának, ill. magyarázatának, az egyértelmü, pontos fogalmazásnak a függvénye” (Illésné Kovács és Simigné Fenyő 2008: 168), és nem a szakkifejezések elhagyásának. 
Úgy gondolom, hogy a megfelelő betegedukáció része, hogy a beteg képes betegségéről, az őt érintő orvosi beavatkozásokról beszélni olyan terminusok használatával, amelyeket a mindennapokban talán mellőz. Ennek fényében állapítható meg az (11) példában is fellelhető fordítási stratégia, amely a magyar és a francia fordításokra is éppúgy jellemző. Ha tehát elfogadjuk a feltételezést, hogy az angol autentikus szövegek voltaképpen intralingvális fordítás eredményképpen keletkezett szövegek, akkor érdemes az idegen szavakra vonatkozó fordítási stratégiát is ebből a szempontból megközelíteni. Ebben a gondolatban a betegtájékoztatókban azonosítható első fordítási stratégia elnevezése példákkal:

I. A tudományos terminus és a rá vonatkozó magyarázat vagy definíció is változatlan marad

(12) Myeloma is literally an "oma," or tumor, involving the "myelo," or blood-producing cells in the bone marrow. The cells that are affected are plasma cells (a type of white blood cell), which are our antibody-producing (immunoglobulin-producing) cells.

(12a) A mielóma a szó szoros értelmében egy „oma”, azaz daganat, ami a „myel$o$ "-t, vagyis a csontvelöben található vértermelö sejteket érinti. Az érintett sejtek a plazmasejtek (a fehérvérsejtek egyik típusa), amelyek az emberi szervezet antitest-termelöi (immunglobulin termelök).

(12b) Le myélome est littéralement un «ome » ou tumeur, impliquant le «myélo », ou les cellules produisant le sang dans la moelle osseuse. Les cellules affectées sont les plasmocytes (une catégorie de leucocytes), qui sont les cellules produisant nos anticorps (ou immunoglobuline).

A (12) angol nyelvű példában és annak magyar és francia fordításán jól látszik, hogy mind az autentikus, mind a fordított szövegek redundánsak, magyarázó jellegüek. Úgy gondolom, hogy ezen felüli információk betoldása, magyarázata valójában a fel- 
dolgozást nehezítő, túlzott redundanciát eredményezne. A szövegek magyarázó jellegét nemcsak a példamondatokban dőlt betüvel szedett, idegen eredetü terminusok és azok köznyelvi megfelelője érezteti, hanem az egyes magyarázó szerkezetek és kötőszók (literally, a szó szoros értelmében, littéralement; or, azaz, ou; involving, impliquant; or, vagyis, ou) megléte, a vonatkozói alárendelésre használt vonatkozói névmások (that, which; ami, amelyek; qui), valamint az idegen eredetü, tudományos terminusok után zárójelben betoldott köznyelvi megfelelök (a type of white blood cell, a fehérvérsejtek egyik típusa, une catégorie de leucocytes)), vagy a köznyelvi terminusok után zárójelben betoldott tudományos terminusok (immunoglobulin-producing, immunglobulin termelök, immunoglobuline).

Ebben a fordítói stratégiában az idegen szavak száma nem feltétlenül nő a fordításokban, bár bizonyos esetekben a magyar szöveg az elemzéshez használt szótárak alapján idegenítőnek érez olyan szakszavakat (pl.: antitest), amelyeket az angol szótár (pl.: antibody) nem érez annak. A betegtájékoztatók magyarázó jellegüek, de a magyarázatban is lehetnek olyan szakkifejezések, amelyek a célnyelvi olvasó számára idegenszerüek.

Az 1. és a 2. ábra rávilágít, hogy gyakorlatilag semmilyen tudományos, idegen eredetü morféma vagy terminus nem marad köznyelvi megfelelö, definíció vagy magyarázat nélkül. Az ábrák bal oldali részén tudományos terminusok vannak, míg a jobb oldali rész inkább a köznyelvhez sorolható. Érdekes, hogy önmagában a bal oldali vagy önmagában a jobb oldali elemek is elengedök lennének az információ átadására, hiszen voltaképpen szinonimákról beszélünk. A szerzők tehát többletinformációt vezetnek be, a szövegeket redundánssá teszik. Közérthetőségre, de mindemellett a tudományos terminusok ismertetésére, magyarázatára is törekednek

Ugyanez a tendencia figyelhető meg a 2. ábrán, ahol a szerzők nem kötőszavakkal, hanem zárójelekbe tett köznyelvi megfelelőkkel vagy tudományos terminussal adnak meg szinonimákat.

A következő azonosított fordítási stratégia lényege, hogy a fordító feltehetőleg túl idegenszerünek érzi az adott terminust, ezért mellékes információként, zárójelben 
meghagyja azt, de alapvetően a köznyelvi megfelelöt részesíti előnyben. Ahogy arra Muñoz-Miquel (2012: 200-202) korábban rámutatott, ez a stratégia leginkább a szövegek elején jellemző. A következő példában rögtön az egyik betegtájékoztató címében találkozunk ezzel a jelenséggel. A jelen stratégiát a korpuszból vett példákkal szemléltetem.

$$
\text { 1. ábra }
$$

A myeloma értelmezése

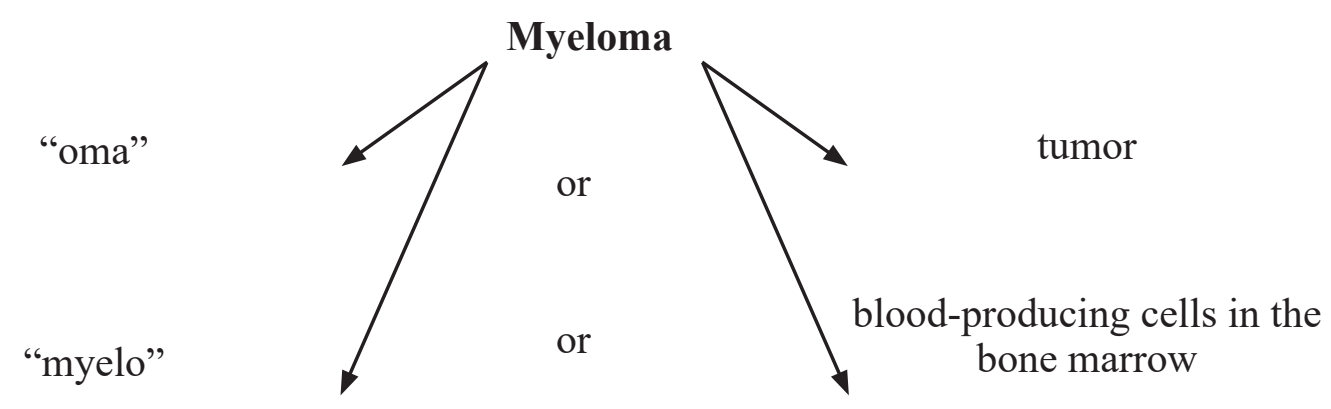

2. ábra

A the cells that are affected értelmezése

the cells that are affected

plasma cells

(immunoglobulin-producing)
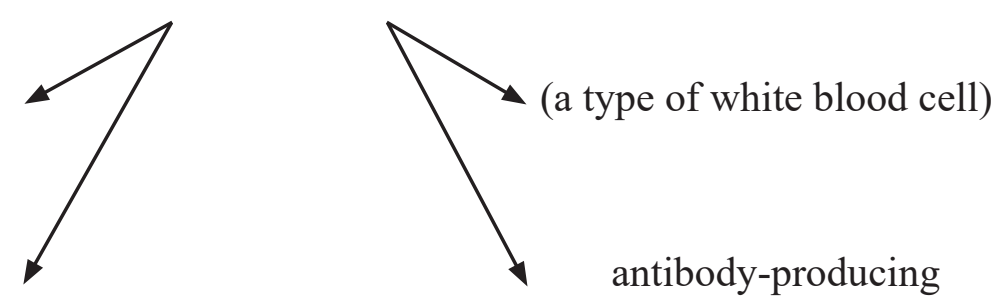

II. Köznyelvi szó betoldása és az idegen eredetű terminus szerepeltetése zárójelben

(13) amniocentesis

(13a) magzatvízvizsgálat (amniocentesis) 
Ez a fordítási stratégia törekszik arra, hogy a beteget megismertesse az adott beavatkozás tudományos megfelelöjével, de a magyar fordítás további részében az amniocentesis idegen eredetü terminus egyszer sem szerepel. Természetesen fontos, hogy ebben az esetben a fordítónak lehetősége nyílik arra, hogy a köznyelvi szót válassza, amit nem tehetne meg akkor, ha például egy betegség hivatalos elnevezéséröl lenne szó (pl.: leukémia vs fehérvérüség), ahogy arra korábban utaltam. A szóban forgó, angol betegtájékoztatóban és annak francia fordításában a kérdéses idegen eredetü terminus (amniocentesis, amniocèntese) 28 alkalommal szerepel. Ez arra utal, hogy a francia fordító nem érzi szükségét, hogy köznyelvi szóval helyettesítse a tudományos terminust, ami azzal magyarázható, hogy angolban és franciában már a köznyelvben is lényegesen magasabb az idegen eredetủ szavak száma, mint a magyarban.

Ezzel szemben a magyar fordításban összesen 1 alkalommal fordul elö az amniocentesis terminus, ahogy a mielómáról szóló tájékoztatóban is 1-szer fordul elő az anemia angol terminus közvetlenül átváltott alakja (anémia), 1-szer a vérszegénység (anémia) alak, és 20 alkalommal a vérszegénység köznyelvi szó. A magyar fordító ezen kívül a következő köznyelvi szavakat használja az amniocentesis terminus magyar megfeleltetésére, összesen 27 alkalommal (a zárójelben pontosítom a szavak előfordulását): magzatvízvizsgálat (17), vizsgálat (9), beavatkozás (1). Rendszerint megfigyelhetö, hogy a fordítás használ terminológiai szinonimát ott, ahol az angol egy terminust használ a szöveg egészén (ismétléskerülési hipotézis):

- mutation (EN)

○ kromoszóma elváltozás (mutáció) (HU), mutáció (HU), genetikai változás (HU);

○ modification (mutation) (FR), altération (mutation) (FR), mutation (FR), - foetus $(\mathrm{EN})$

○ magzat (HU), születendö gyermek (HU), gyermek (HU);

○ foetus (FR), bébé (FR), enfant (FR). 
Angolról magyarra fordításokban szintén megfigyelhető, hogy az idegen eredetü terminusok és a köznyelvi szavak a szövegben folyamatosan váltják egymást, hogy a fordító igyekszik szinonimákat használni ott, ahol a FNYSZ nem teszi. A fordított szövegekben használt szinonimák között is lehetnek azonban LGA terminusok, és a forrásnyelvi tudományos terminus is minden esetben szerepel a fordításban. Ennek értelmében bár a fordító törekszik köznyelvi szavak használatára, az idegen szavak száma a fordításokban feltehetőleg nem lesz jelentősen kevesebb. Sőt, a fordító valójában a zárójelben való pontosítást is többször végig viszi a szöveg egészén, ahogy azt a következő példák szemléltetik:

- translocation $(6) \rightarrow$

- duplication (3) $\rightarrow$

- insertion (3) $\rightarrow$

- inversion (4) $\rightarrow$ transzlokáció (áthelyeződés) (a tájékoztató legelején szerepel) (1), transzlokáció (4), átrendeződés (1);

- chromosome deletion (6) $\rightarrow$ kromoszóma törlődés (deléció) (a tájékoztató legelején), kromoszóma deléciók (tőrlődések) (2), deléció (2), kihagyás (1);

duplikációk (kettőződés) (a tájékoztató legelején), megkettőződés (duplikáció), kihagyás (1); hozzáadás (inszerció) (a tájékoztató legelején), inszerció (hozzáadás), inszerció;

megfordulás (inverzió) (a tájékoztató legelején), inverzió (megfordulás), inverzió (1).

Úgy gondolom, hogy a jelen példák is rámutatnak a korábban felvetett feltételezésre,amely szerint a fordító (vagy a szöveg szerzője) feltett szándéka, hogy az olvasó megismerje az adott betegség, beavatkozás szakterminológiájának egy részét. Az utóbbi felsorolás két utolsó példájában is látható, hogy a fordító először a tudományos termi- 
nust szerepelteti mellékinformációként, zárójelbe téve. A szöveg további részén azonban a köznyelvi szó szerepel a tudományos terminus után tett zárójelben, míg végül a köznyelvi szót a fordító elhagyja, és csak a tudományos terminust szerepelteti.

Mielőtt rátérek a következő stratégiára, a II. stratégiára az előzőktől némileg különböző példát hozok. Ebben az esetben a fordító nemcsak az angol zárójelben szereplö mozaikszót és annak az angol szövegben is szereplő feloldását tartja meg, hanem mindezt zárójelbe téve megadja a fogalom magyar vagy francia tudományos megfelelöjét. Ilyen esetekkel akkor találkozhatunk, ha az angol mozaikszó elterjedt, használatos a magyar és a francia klinikumban is, de ismerete feltehetőleg a szakemberekre korlátozódik. Ezekben az esetekben a FNYSZ idegen szavainak száma voltaképpen kétszeresére nő, hiszen az összetett angol terminus mellett a célnyelvi tudományos megfelelő is szerepel.

(14) The very earliest stage is called Monoclonal Gammopathy of Undetermined Significance (MGUS).

(14a) A legkorábbi stádiumot bizonytalan jelentőségü monoklonális gammopátiának (MGUS, monoclonal gammopathy of undetermined significance) nevezik.

(14b) Le stade le plus précoce est appelé gammapathie monoclonale de signification indéterminée (MGUS, Monoclonal Gammopathy of Undetermined Significance).

Előfordul, hogy az adott kontextus lehetőséget ad arra, hogy a fordító kihagyja az idegen eredetü terminust.

Ezen a ponton érkezünk el a következő fordítói stratégiához: 
III. Idegen eredetű terminus kihagyás

(15) Making a decision about having an amniocentesis test during pregnancy can be difficult. It is important to remember that you do not have to take the amniocentesis test if you do not want to.

(15a) Nem könnyü döntést hozni arról, hogy a terhesség során Ön szeretné-e a vizsgálatot. Fontos, hogy tudja, hogy ez nem kötelezö.

(16) How long will it take to get the results of the amniocentesis?

(16a) Mennyi időbe telik, amíg kézhez kapom az eredményeket?

(17) Monitored by tracking monoclonal protein in serum using Serum Protein Electrophoresis (SPEP) (IgG) and/or quantitative immunoglobulin (QIG) measurement $(\operatorname{Ig} \mathrm{A} / \mathrm{D} / \mathrm{E})$.

(17a) Monoklonális fehérje ellenőrzése szérum elektroforézissel (IgG) vagy/és immunglobulin (QIG) méréssel (IgA/D/E).

Ez a stratégia csak akkor figyelhető meg, ha a szóban forgó terminus elhagyható. Erre egyrészt akkor van lehetőség, ha például a fenti példában (15a) bemutatott mutató névmás (ez) alkalmas arra, hogy anaforikus funkciójának köszönhetően visszautaljon antécédensére (a vizsgálat). Lehetséges a megoldás akkor is, ha a kontextus egyértelmüvé teszi, hogy pontosan miről van szó, és a fordító nem terheli felesleges információkkal az olvasót (16a). Lehetséges a stratégia továbbá akkor, ha az angol szövegben többletinformáció van, mint ahogy az a (17) példában (SPEP) is megfigyelhető. Ezekben az esetekben a fordító feltehetőleg túlzott redundanciának véli a terminológiai szinonimák használatát, és egyetlen terminussal váltja át az angolban két terminussal pontosított fogalmat.

Efféle túlzott forrásnyelvi redundanciáról beszélhetünk akkor, amikor az angol szövegben a tudományos terminust magyarázat követi, de valójában a köznyelvi szinonima is megállná a helyét, vagy a terminus voltaképpen nem szorul magyarázatra. Érdekes, hogy a következő példában a magyarázat a magyarban és a franciában is elmarad, de ettől 
függetlenül magát a tudományos terminust a francia megtartja, a magyar pedig köznyelvi szóval helyettesíti. Ez a példa ugyancsak rámutat, hogy az egyes fordítási stratégiák nem kizárólagosak, hiszen ebben az esetben is beszélhetünk az idegen szóra vonatkozó zárójeles megjegyzés kihagyásáról, a francia esetén magyarázat nélküli átváltásról (pl. 18b), a magyar esetén pedig a tudományos terminus köznyelvi szóval való helyettesítéséről (pl. 18a). Az újlatin ajkú francia olvasó számára valószínűleg nem igényel magyarázatot a prognosis terminus, a magyar olvasót figyelembe véve pedig feltehetőleg célravezetőbb a köznyelvi szó választása. A számadatok alapján azonban ez a fordítói stratégia ritkábban alkalmazott, hiszen a CNYSZ-ben több LGA terminus azonosítható, mint a FNYSZ-ben.

(18) The prognosis (from the Greek words that mean "knowing ahead") [...] is better when treatment is started early and bone disease or other complications can be prevented.

(18a) A [...] betegek kilátásai jobbak, ha a betegség kezelése korán elkezdődik, megelőzve a csontbetegségek és egyéb szövődmények kialakulását.

(18b) Le pronostic pour les patients [...] est meilleur lorsque le traitement commence tôt et la maladie osseuse ou d'autres complications peuvent être évitées.

Újabb stratégiát fedezhetünk fel, amikor a fordító ugyancsak köznyelvi szóval felelteti meg az idegen eredetű terminust, de nem érzi szükségét, hogy megadja a tudományos terminust is. Ezek az esetek egyrészt általában a kevesebbszer előforduló terminusokra jellemzőbbek, amelyek ismerete nem feltétlenül fontos a beteg számára, hiszen az adott betegséghez vagy beavatkozáshoz közvetlenül nem kapcsolódnak. Másrészt akkor azonosíthatjuk ezt a stratégiát, ha a köznyelvi megfelelő az egészségügyi szakszemélyzet által is tökéletesen elfogadott, a fogalmat jól lefedő elnevezés. Ez az eljárás is elsősorban a magyar fordításokban figyelhető meg. Az angol és a francia korpuszban például nem szerepel köznyelvi megfelelöje a placenta, rectum, transmission, cornea, pleura, peritoneum 
terminusoknak, a magyarban pedig maga a tudományos terminus nem szerepel, csak a köznyelvi megfelelője (méhlepény, végbél, átadás, szaruhártya, mellhártya, hashártya). Anatómiai megnevezéseknél itt rendszerint metonimikus kapcsolat (szinechdoché) van a két fogalom között, hiszen a rendkívül precíz anatómiai terminus helyett általánosabb, „nagyobb területet jelölő” megfelelőt választunk. Érdekes, hogy ez a stratégia akkor is azonosítható, ha az angol szerepelteti a tudományos terminust és a köznyelvi megfelelöt is, de a magyar köznyelvi megfelelőt és közérthető definíciót használ [pl.: cervix (entrance to womb) $\rightarrow$ méhnyak, a méh bejárata]. A stratégia nem csökkenti a CNYSZ idegen szavainak számát, hiszen ahogy fentebb írtam, alapvetően a kevesebbszer előforduló, az adott betegség szempontjából nem kulcsfontosságú fogalmak megnevezéséről van szó. A következő azonosítható fordítói stratégia ennek értelmében:

IV. Az idegen eredetű terminus megfeleltetése köznyelvi szóval

(19) You have had another type of test that is done during pregnancy (such as an ultrasound, nuchal translucency scan or blood test). It has shown that there is an increased risk that your baby has a genetic condition.

(19a) A terhességi szürővizsgálatok során (ultrahang, nyaki bőrredő vizsgálata, vérvizsgálat) az Ön eredménye arra utal, hogy magzatának fokozott az esélye egy esetleges genetikai betegségre.

(19b) Vous avez eu un autre type d'examen pendant votre grossesse (échographie, mesure de la clarté nucale ou test sanguin). Cet examen montre qu'il existe un risque que votre bébé soit atteint d'une maladie génétique.

A (19) példamondat érdekessége, hogy háromszorosan összetett terminust mutat be (nuchal translucency scan), amelyek mindegyike önállóan is terminusértékü. A magyar szöveg mindhárom terminust köznyelvi szóval váltja fel, míg a francia kettőt köznyelvi szóval feleltet meg (mesure, clarté), egy alkalommal pedig megtartja a tudományos terminust (nucale). Ezt azért tartom érdekesnek és fontosnak, mert a példa rávilágít, hogy 
összetett terminusok esetén a fordítói stratégiák váltakozhatnak, használatuk nem kizárólagos. Többtagú terminusok fordításánál adott esetben több fordítási stratégia is azonosítható. Különösen érdekesnek tartom ezt az eljárást akkor, amikor a fordító a tudományos terminus megtartása mellett olyan köznyelvi szó betoldását választja, amelynek metaforikus stilisztikai értéke van. A következő példa erre a stratégiára mutat rá.

(20) The cells activate osteoclast cells, which destroy bone, and block osteoblast cells, which normally repair damaged bone.

(20a) A sejtek aktiválják az oszteoklaszt (csontfaló) sejteket, melyek elpusztítják a csontokat és blokkolják a csontképző sejteket, melyek normál esetben helyrehozzák a csontkárosodást.

V. A tudományos terminus átváltása magyarázat vagy definíció nélkül

(21) Common conditions inherited in this way include fragile X, Duchenne muscular dystrophy and haemophilia.

(21a) Az ily módon örökölt betegségek pl. a fragilis X szindróma, a Duchenne izomdisztrófia és a hemofilia.

(21b) Des exemples de maladies liées à l'X sont le syndrome de l'X fragile, la $d y$ strophie musculaire de Duchenne et l'hémophilie.

(22) What is autosomal recessive inheritance?

(22a) Mi az autoszomális recesszív öröklödés?

(22b) Qu'est-ce que l'hérédité autosomique récessive?

Megesik, hogy a fordító valami miatt az idegen eredetủ tudományos terminust átváltja a fordításban, és nem is füz hozzá definíciót vagy magyarázatot. Ez a stratégia 
hasonlít az első azonosított stratégiára. A különbség az, hogy az ötödik stratégia esetében az LGA terminusok lexikai környezetében sem a FNYSZ, sem a CNYSZ nem használ az LGA terminusokra vonatkozó magyarázatokat, egyik nyelv sem told be köznyelvi szavakat, szinonimákat az LGA terminusok előtt vagy után.

Ezekben az esetekben véleményem szerint az készteti a fordítót a magyarázat, definíció betoldásának elhagyására, hogy egyrészt az adott betegségek a betegtájékoztató további részében nem kapnak kiemelt hangsúlyt, nem fontosok azoknak, akik nem ezekben a betegségekben szenvednek. Másrészt feltételezhető, hogy bár az izomdisztrófia második tagja idegen eredetü terminus, a hibrid első tagja (izom) köznyelvi szó, a hemofília pedig talán többek számára ismeretes betegség. A (22) példában pedig feltehetőleg azért marad el a magyarázat, mert a példa valójában egy alfejezet címét jelöli. Ahogy korábban rámutattam, az idegen szavak elemzésekor fontos elemzési lépés az idegen szavak kontextusa, hiszen a jelen esetben sem beszélhetünk a tudományos terminus magyarázatának elmaradásáról, mert külön alfejezetet szenteltek arra, hogy definiálják az autoszomális recesszív öröklődést. Erre csak akkor deríthetünk fényt, ha nemcsak az idegen szavak számát, hanem kontextusát is tanulmányozzuk. A stratégia használatával tovább nő a CNYSZ idegen szavainak száma. Ugyanez jellemző a következő fordítási stratégiára is.

A következő részben olyan példákat mutatok be, amelyekre jellemző, hogy a fordító tudományos terminust használ, de a tudományos terminus eltér attól, amelyet a FNYSZ szerzője használt. Ez a fordítási stratégia a korpuszban angolról franciára fordításokban figyelhetö meg.

VI. A tudományos terminus megfeleltetése más tudományos terminussal

(23) Some examples of genetic conditions include Down's syndrome, cystic fibrosis and muscular dystrophy.

(23a) Quelques exemples de maladies génétiques sont la trisomie 21, la mucoviscidose ou les myopathies. 
A magyar fordításban akkor figyelhetjük meg ezt a stratégiát, ha az angol FNYSZ mozaikszót használ, a magyar fordító pedig ezt feloldani igyekszik (pl.: 24-24a). Fel is oldja, de minden mozaikszó minden betűjét talán lehetetlen köznyelvi szóval helyettesíteni. Ezért sorolom ezt az eljárást abba a kategóriába, amikor bár részlegesen, de a magyar fordító más tudományos terminust használt, mint az angol, vélhetőleg azért, mert az adott mozaikszó a célnyelvi laikus számára a legkevésbé sem ismert.

(24) Both SPEP and UPEP are negative (no monoclonal spike in serum or urine).

(24a) Mind a szérum, mind pedig a fehérje elktroforézis vizsgálat is negatív (nincs monoklonális tüske sem a szérumban, sem a vizeletben).

Ez a fordítási stratégia rávilágít a terminológiai szinonimák fontosságára. Az orvosi szaknyelv kötöttsége ellenére ismer terminológiai szinonimákat, és egy orvostudományi fogalmat nemcsak több köznyelvi szó, de több tudományos terminus is jelölhet. Érdekes, hogy az angol FNYSZ-ben (23) szereplő eponimát (Down's syndrome) a francia fordító a betegséget okozó 21. kromoszómapárra (trisomie 21) való átváltással felelteti meg a betegséget először leíró orvosról elnevezett tulajdonneves változat helyett. Úgy gondolom, hogy érdekes kutatásokat lehetne végezni abban a tekintetben, hogy az adott nyelvek és kultúrák mennyire törekszenek az eponimák vagy egyéb kulturális elemek használatára vagy elhagyására. A Down-kór története különösen érdekes, hiszen a betegséget diagnosztizáló orvos korában a szindrómát mongolizmusnak nevezték. E pejoratív jelölés ma már természetesen minden kontextusban kerülendő. Érdekesnek tartom, hogy a szaknyelvi kötöttség ellenére az orvosi szövegnél is fontos kérdéseket vethetnek fel a kulturális elemek, ahogy arra az imént utaltam. A korpuszomban észrevehető, hogy a fordító esetenként teljes bekezdéseket hagy ki, ha úgy érzi, hogy az adott szövegrész a fordítás nyelvének kultúrájában nem releváns. Itt azonban kevésbé beszélhetünk az idegen szavak kihagyásának fordítói stratégiájáról, sokkal inkább a szöveg pragmatikai adaptációjáról van szó. Az alábbi angol szövegrészlet fordítása mindenesetre elmaradt mind a magyar, mind a francia fordításban. 
There is an increased risk of having a child with a particular genetic condition because of your ethnic background. Examples of this include sickle cell in people of Afro-Caribbean descent, beta-thalassaemia in people of Mediterranean descent, cystic fibrosis in people of Western European descent and Tay Sachs in people of Ashkenazi Jewish descent. (Guy's and St Thomas' Hospital, the Royal College of Obstetricians and Gynaecologists, London IDEAS Genetic Knowledge. 2007: 4)

Az elemzés második kutatási kérdése arra irányult, hogy milyen fordítási stratégiákat alkalmaz a fordító az adott korpuszban az idegen szavak megfeleltetésekor, hogy hogyan igyekszik kielégíteni a laikus célnyelvi olvasó igényeit. Elemzésemben összesen hat fordítási stratégiát állapítottam meg: a tudományos terminus és a rá vonatkozó magyarázat vagy definíció is változatlan marad (I.), köznyelvi szó betoldása és az idegen eredetü terminus szerepeltetése zárójelben (II.), LGA kihagyása (III.), idegen eredetű terminus megfeleltetése köznyelvi szóval (IV.), a tudományos terminus átváltása magyarázat vagy definíció nélkül (V.), a tudományos terminus megfeleltetése más tudományos terminussal (VI.).

\section{5. Összefoglalás és kitekintés}

Az elemzés eredményei rámutatnak, hogy az adott szövegek vizsgálata alapján az autentikus angol szövegekre kevésbé jellemző az idegen eredetű terminusok használata, mint a fordított francia alkorpuszra. A legtöbb idegen szót a fordított magyar alkorpuszban azonosítottam. Ennek oka a nyelvek szókészleti különbségeiben keresendő, hiszen az angol köznyelvben alapvetően több LG terminus használatos, mint a magyarban, tehát a magyar beszélő idegenítőnek érzékelhet olyan terminusokat, amelyek az angolban a laikusok számára nem okoznak jelentős feldolgozási erőfeszítést. Fontos megjegyezni, hogy a magyar és a francia orvosi nyelvbe szüntelenül beáramló angol szakkifejezések növelik az idegen szavak számát, az angolban pedig értelemszerüen nem hatnak idegenszerủen az angolul elnevezett szakkifejezések. A betegedukáció része, hogy a betegek megismerkednek a be- 
tegségüket megnevező, illetve az arra alkalmazott kezelések legfontosabb terminusaival, hogy hatékonyan tudjanak kommunikálni az őket gondozó szakszemélyzettel. A fordítók ezért is törekedhetnek az idegen szavak használatára. Arra következtethetünk azonban, hogy a magyar és a francia célnyelvi olvasónak a felsorolt okok miatt nagyobb feldolgozási erőfeszítésébe telik a betegtájékoztatók megértése.

Felmerül továbbá a kérdés, hogy milyen eredményeket kapnánk, ha az elemzéshez nem az adott nyelveken írt idegen szavak szótárát használnánk, hanem hatásvizsgálatot végeznénk angol, francia és magyar anyanyelvi beszélők körében. Lehetséges, hogy maguk a szótárak sem teljesen azonos rendszerező elvek mentén gyüjtötték össze az idegen szavakat. A kutatás folytatásában vállalkozom a hatásvizsgálat elvégzésére.

Az elemzés a kutatási irány első eredményeit mutatja be, amelyet a jövőben más adatokkal célszerü kiegészíteni. A kutatás folytatásában tervezem elkülöníteni egymástól az idegen szavakat eredetük szerint. Ennek fényében arról is információt kaphatunk, hogy a vizsgált nyelveken milyen arányban fordulnak elö görög-latin, angol, esetleg más eredetủ idegen szavak. Tervezem továbbá a lexikai és a grammatikai szavak elkülönítését, hiszen a vizsgált nyelvekre más nyelvtani szerkezetek jellemzők, így további különbségek várhatók az eredmények tekintetében.

A kutatás folytatásában a párhuzamos korpuszelemzést összehasonlítható korpuszelemzéssel tervezem kiegészíteni. Az összehasonlítható korpusz rávilágít arra a kutatás szempontjából fontos kérdésre, hogy bizonyos szavak, terminusok gyakrabban fordulnak-e elö az azonos nyelvü fordított alkorpuszban, mint a nem fordított alkorpuszban, hogy az idegen szavak gyakorisága a két alkorpuszban eltérő-e, hogy azonosítható-e eltolódás.

A kutatásban a betegtájékoztatókra intralingvális fordítás eredményeképpen tekintek, ahol a FNYSZ szerzői az anyanyelvükön igyekeznek a laikus olvasó igényeihez igazítani a betegtájékoztatók szövegét. A fordító az elemzett korpusz alapján arra törekszik, hogy az intralingvális fordítás során keletkező betoldásokat, explicitációkat, magyarázatokat és definíciókat megtartja. Ez azért is fontos, mert az orvosi szaknyelven akkor 
is jelentős az idegen szavak ismerete, ha nem orvos-orvos kommunikációról van szó, hiszen hozzátartozik a betegedukációhoz, hogy ne csak az orvos alkalmazkodjon a laikus nyelvhasználóhoz, hanem a beteg is megértse, ismerje a betegségével kapcsolatos alapvetö fogalmakat, terminusokat.

A fordítási stratégiákat illetően összesen hat eljárást azonosítottam az általam vizsgált párhuzamos alkorpuszokban. A magyar és a francia fordító bizonyos esetekben megtartja a tudományos terminust és a rá vonatkozó magyarázatot vagy definíciót (I.), mert a FNYSZ eléggé explicit ahhoz, hogy a laikus befogadó igényeit kielégítse, és a további explicitáció túlzott redundanciát eredményezne. A következő stratégia (II.) lényege, hogy a fordító szerepelteti a forrásnyelven is meglévő idegen eredetủ terminust, de zárójelbe teszi, és köznyelvi szót használ a megfeleltetéskor. Ez a stratégia leginkább betegtájékoztatók elején figyelhető meg, az idegen eredetü terminus első előfordulásakor, illetve akkor, ha az angol terminus elterjedt, használatos a magyar és francia klinikumban is, de ismerete feltehetőleg a szakemberekre korlátozódik. A stratégia a magyarra fordításra jellemző, mert a francia fordító nem érzi szükségét, hogy köznyelvi szóval helyettesítse a tudományos terminust, ami azzal magyarázható, hogy angolban és franciában már a köznyelvben is lényegesen magasabb az idegen eredetủ szavak száma, mint a magyarban, ahogy arra fentebb utaltam. Lehetőség van az LGA terminus kihagyására (III.), ha a fordító más nyelvi elemmel helyettesíti azt (pl.: mutató névmás); ha a kontextus egyértelművé teszi, hogy pontosan miről van szó, ezért az idegen szó elhagyható; vagy ha a tudományos terminus, vagy annak esetleges további terminológiai szinonimákkal való együttes jelenléte túlzott redundanciát okozna. Újabb stratégiát állapíthatunk meg, amikor a fordító köznyelvi szóval felelteti meg az idegen eredetű terminust (IV.). Ezekben az esetekben általában egyrészt a ritkábban előforduló terminusok érintettek, amelyek ismerete nem feltétlenül fontos a beteg számára, hiszen az adott betegséghez vagy beavatkozáshoz közvetlenül nem kapcsolódnak. Másrészt akkor használható ez a stratégia, ha az adott köznyelvi elnevezés az egészségügyi szakszemélyzet számára is tökéletesen elfogadott, a kérdéses fogalmat kellőképpen lefedi. Ez az eljárás is elsősorban a magyar fordításokban figyelhető meg a korábban bemutatott okok miatt. A fordító a tudományos terminust átválthatja magyarázat vagy definíció nélkül (V.), ha az adott betegségek a fordító szerint a laikus célközönség 
számára is nagy valószínűséggel ismertek, vagy ha a betegtájékoztató további részében nem kapnak kiemelt hangsúlyt, nem fontosok azok számára, akik érintettek az adott betegségben. Az idegen eredetü tudományos terminus megfeleltetése más idegen eredetü tudományos terminussal (VI.) angolról franciára való fordításban figyelhető meg, és felhívja a figyelmet az orvosi szaknyelven is meglévő terminológiai szinonimák ismeretének fontosságára.

A stratégiák tekintetében megállapítható, hogy a hat fordítási stratégia közül csupán kettő (III.) és (IV.) esetében figyelhető meg a FNYSZ idegen eredetü terminusának kihagyása vagy helyettesítése köznyelvi szóval. Ezekre a stratégiákra azonban csak akkor kerül sor, ha a tudományos terminus elhagyható (pl.: névmás használata a célnyelven), vagy a kevesebbszer előforduló terminusokról van szó, amelyek ismerete nem feltétlenül fontos a beteg számára, hiszen az adott betegséghez vagy beavatkozáshoz közvetlenül nem kapcsolódik. A másik négy stratégia növeli a CNYSZ idegein szavainak számát.

A kutatást a továbbiakban érdemes lenne elvégezni újabb kiadású idegen szavak szótár segítségével. Ezek az eredmények azért is lennének érdekesek, mert rávilágítanának, hogyan változik a vizsgálat szempontjából releváns nyelvekben az idegen szavak gyakorisága. Érdemesnek tartanám a vizsgálatot kiterjeszteni további műfajokra: internetes betegtájékoztatókra, beleegyező nyilatkozatokra stb. Fontos lenne bevonni az elemzésbe az orvos-orvos diasztratikus változat műfajait, mint például a zárójelentés. A két egymástól eltérő mủfajból lehetne következtetni azokra a terminushasználati különbségekre és fordítási stratégiákra, amelyek az orvos-orvos és az orvosi-laikus kommunikáció közötti eltérésekre jellemzők. Ugyancsak izgalmas eredmények születhetnének olyan vizsgálatokból, amelyek az intralingvális fordítást is bevonják az elemzésbe, hiszen a betegtájékoztatók is intralingvális fordítás eredményei. Efféle vizsgálattal általános képet nyerhetnénk arról, milyen gyakorisággal használnak LGA terminusokat az orvos-orvos diasztratikus változat részvevői anyanyelvükön, és hogy hogyan és milyen formában változik ez a gyakoriság az intra- és interlingvális fordítás folyamatában. 


\section{Irodalom}

Baker, M. 1993. Corpus Linguistics and Translation Studies - Implications and Applications. In Baker, M. et al (eds.) Text and Technology. In Honour of John Sinclair. Amsterdam/Philadelpia: Jonh Benjamins. 233-250. https://doi.org/10.1075/z.64. $\underline{15 \mathrm{bak}}$

Baker, M. 1996. Corpus-based translation studies: The challenges that lie ahead. In: Somers, H. (ed) Terminology, LSP and Translation. Studies in language engineering in honour of Juan C. Sager. Amsterdam/Philadelphia: John Benjamins. 175186. https://doi.org/10.1075/btl.18.17bak

Bakos F. 2013. Idegen szavak és kifejezések szótára. Budapest: Akadémiai Kiadó.

Bősze P. 2011. Latin, magyar, angol? A magyar orvosi szaknyelvröl. Debreceni Szemle. Vol. 19. No. 4. 369-374.

Cselovszkyné Tarr K. 1999. Tabu és eufemizmus az egészségügy nyelvében. Pécs: Pécsi Tudományegyetem.

Demers, G. 1991. L'euphémisme en anglais et en français. Langues et Linguistique. No. 17. 17-37.

Fazekas E. 2007. Bevezetés a magyar nyelvtörténetbe. Kolozsvár: Egyetemi Mühely Kiadó.

Heltai P. 2004. Terminus és köznyelvi szó. In: Dróth J. (ed.) Szaknyelv és szakforditás. Gödöllő: Szent István Egyetem. 25-46.

Illésné Kovács M., Simigné Fenyő S. 2008. A metainformációs nyelvi elemek funkciója a közvetett kommunikáció egyik fajtájában, betegtájékoztatók szövegében. Alkalmazott Nyelvészeti Közlemények. Miskolc: Miskolci Egyetem. 161-171.

Illésné Kovács M., Simigné Fenyő S. 2009. Gyógyszerészeti kísérőiratok kommunikációs szempontú elemzése Hymes szociokulturális modellje alapján. In: Gecső T., Sárdi 
Cs. (eds.) A kommunikáció nyelvészeti aspektusai. Budapest: Tinta Tankönyvkiadó. Székesfehérvár: Kodolányi János Főiskola. 141-148.

Jamet, D. 2010. Historique et procédés linguistiques de l'euphémisme. In: Jamet, D. et Jobert, M. (eds) Empreintes de l'euphémisme. Tours et détours. Paris: L'Harmattan. $30-49$.

Jiménez-Crespo, M. Á., Tercedor Sánchez, M. 2017. Lexical variation, register and explicitation in medical translation. A comparable corpus study of medical terminology in US websites translated into Spanish. Translation and Interpreting Studies. Vol. 12. No. 3. 405-426. https://doi.org/10.1075/tis.12.3.03jim

Kenny, D. 1998. Creatures of Habit? What Translators Usually Do with Words. Meta. Vol. 43. No. 4. 515-523. https://doi.org/10.7202/003302ar

Klaudy K. 2001. Az aszimmetria hipotézis. In: Bartha M. (szerk.). A X. Magyar Alkalmazott Nyelvészeti Konferencia elöadásai. Székesfehérvár: KJF. 371-378.

Kurtán Zs. 2003. Szakmai nyelvhasználat. Budapest: Nemzeti Tankönyvkiadó.

Lanstyák I. 2006. A kölcsönszavak rendszerezéséröl. In: Nyelvböl nyelvbe. Tanulmányok a szó kölcsönzésről, kódváltásról és fordításról. Pozsony: Kalligram Könyvkiadó. $15-56$.

Meyer, I., Mackintosh, K. 2000. When terms move into our everyday lives: an overview of determinologization. Terminology. Vol. 6. No. 1. 111-138. https://doi.org/10.1075/ term.6.1.07mey

Mihály A. 2006. Anatomia Essentialis. I. kötet. Egységes kötet orvostanhallgatók számára. Szeged: Szegedi Tudományegyetem, Általános Orvostudományi Kar, Anatómiai, Szövet- és Fejlődéstani Intézet.

Montalt Resurrecció, V. 2011. Medical translation. In: Chapelle, C. A. (ed) Encyclopedia of Applied Linguistics. Hoboken, NJ: Wiley. 3649-3653. 
Montalt Resurrecció, V., González Davies, M. 2007. Medical Translation Step by Step. Translation Practices Explained. Manchester: St. Jerome.

Muñoz-Miquel, A. 2012. From the original article to the summary for patients: Reformulation procedures in intralingual translation. Linguistica Antverpiensia. No. 11. 187-206.

Nisbeth Jensen, M., Zethsen, K. K. 2012. Patient information leaflets: Trained translators and pharmacists-cum-translators - a comparison. Linguistica Antverpiensia New Series. Themes in Translation Studies. No. 11. 31-49.

Putz O. 2012. Idegen szavak napjaink orvosi szaknyelvében. In: Horváthné Molnár K., Sciacovelli, A. D. (eds.) Az alkalmazott nyelvészet regionális és globális szerepe. A XXI. Magyar Alkalmazott Nyelvészeti Kongresszus elöadásai. Budapest-Szombathely-Sopron: MANYE-NYME. 365-371.

Robin E., Dankó Sz., Götz A., Nagy A. L., Pataky É., Szegh H., Török G., Zolczer P. 2016. Fordítástudomány és korpuszkutatás: bemutatkozik a Pannónia Korpusz. Fordítástudomány. 18. évf. 2. szám. 5-26.

Seidl-Péch O. 2018. Melyek a (szak)fordító és a fordításkutató munkáját segítő legfontosabb nyelvi korpuszok? In: Robin E. - Zachar V. (szerk.): Forditástudomány ma és holnap. Budapest: L'Harmattan Kiadó. 175-191.

Speake, J. 1997. The Oxford Dictionary of Foreign Words and Phrases. Oxford: Oxford Univerity Press.

Tótfalusi I. 2008. Idegenszó-tár. Idegen szavak értelmezö és etimológiai szótára. Budapest: Tinta Könyvkiadó.

Tournier, J. 1985. Introduction descriptive à la lexicogénétique de l'anglais contemporain. Paris-Genève: Champion-Slatkine.

Varga É. K. 2014. Anatómiai nevek régen és ma. Latin helyett angol? Modern Nyelvoktatás. Vol. 20. No. 1-2. 35-42. 
Warren, B. 1992. What euphemisms tell us about the interpretation of words. Studia Linguistica. Vol. 46. No. 2. 128-172. https://doi.org/10.1111/j.1467-9582.1992. $\underline{\text { tb00833.x }}$

Wright, S. E. 2011. Scientific, technical and medical translation. In: Malmkjaer, K., Windle, K. (eds.) The Oxford Handbook of Translation Studies. Oxford: Oxford University Press. 243-261.

Zethsen, K. K. 2004. Latin-based terms: True or false friends? Target. Vol. 16. No. 1. $125-142$.

\section{Internetes hivatkozások}

AntConc 3.5.0. Elérhetö: https://www.laurenceanthony.net/software/antconc/

Betegségek Nemzetközi Osztályozása (BNO). Elérhető: www.webbeteg.hu/keresok/ bno/13403

MemoQ. Elérhető: https://www.memoq.com/

VariMed adatbázis. Elérhető: varimed.ugr.es

WordSmith Tools 6.0. Elérhetö: https://lexically.net/wordsmith/version6/

\section{Források}

\section{Az autentikus angol korpusz}

G.M. Durie, Brian. 2012/2013. Multiple Myeloma, Cancer of the Bone Marrow. Patient Handbook. North Hollywood: International Myeloma Foundation. http://www. amen.org.i1/wp-content/uploads/2012/02/Patient_Handbook_2013.pdf 
Guy's and St Thomas' Hospital, the Royal College of Obstetricians and Gynaecologists, London IDEAS Genetic Knowledge. 2009. Carrier Testing. Leuven: EuroGentest. http://www.eurogentest.org/fileadmin/templates/eugt/leaflets/pdf/english/carrier testing.pdf

Guy's and St Thomas' Hospital, the Royal College of Obstetricians and Gynaecologists, London IDEAS Genetic Knowledge. 2007. Chromosome Changes. Leuven: EuroGentest. http://www.eurogentest.org/fileadmin/templates/eugt/leaflets/pdf/ english/chromosome_changes.pdf

Guy's and St Thomas' Hospital, the Royal College of Obstetricians and Gynaecologists, London IDEAS Genetic Knowledge. 2007. Chromosome Translocations. Leuven: EuroGentest.http://www.eurogentest.org/fileadmin/templates/eugt/leaflets/pdf/ english/chromosome_translocations.pdf

Guy's and St Thomas' Hospital, the Royal College of Obstetricians and Gynaecologists, London IDEAS Genetic Knowledge. 2007. Dominant inheritance. Leuven: EuroGentest. http://www.eurogentest.org/fileadmin/templates/eugt/leaflets/pdf/ english/Dominant_Inheritance.pdf

Guy's and St Thomas' Hospital, the Royal College of Obstetricians and Gynaecologists, London IDEAS Genetic Knowledge. 2007. Frequently Asked Questions about Genetic Testing. Leuven: EuroGentest. http://www.eurogentest.org/fileadmin/templates/eugt/leaflets/pdf/english/FAQ.pdf

Guy's and St Thomas' Hospital, the Royal College of Obstetricians and Gynaecologists, London IDEAS Genetic Knowledge. 2007. Recessive inheritance. Leuven: EuroGentest. http://www.eurogentest.org/fileadmin/templates/eugt/leaflets/pdf/english/ recessive_inheritance.pdf

Guy's and St Thomas' Hospital, the Royal College of Obstetricians and Gynaecologists, London IDEAS Genetic Knowledge. 2007. The Amniocentesis Test: Information for Patients and Families. Leuven: EuroGentest. http://www.eurogentest.org/fileadmin/templates/eugt/leaflets/pdf/english/amniocentesis.pdf 
Guy's and St Thomas' Hospital, the Royal College of Obstetricians and Gynaecologists, London IDEAS Genetic Knowledge. 2007. What is a Genetic Test? Leuven: EuroGentest. http://www.eurogentest.org/fileadmin/templates/eugt/leaflets/pdf/ english/genetic_test.pdf

International Society for Stem Cell Research. 2008. Patient Handbook on Stem Cell Therapies. Skokie: International Society for Stem Cell Research.http://www.isscr.org/ docs/default-source/patient-handbook/isscrpatienthandbook.pdf

\section{A fordított francia korpusz}

G.M. Durie, Brian. 2015. Myélome multiple, Cancer de la moelle osseuse. Guide du patient. North Hollywood: International Myeloma Foundation. https://www.myeloma. org/sites/default/files/images/publications/International/PDF/french/guide_du_ patient.pdf

Guy's and St Thomas' Hospital, the Royal College of Obstetricians and Gynaecologists, London IDEAS Genetic Knowledge. 2007. Amniocèntese : information pour les malades et leurs familles. Leuven: Orphanet. Fordította: Orphanet. http://www. eurogentest.org/fileadmin/templates/eugt/leaflets/pdf/french/amniocentesis.pdf

Guy's and St Thomas' Hospital, the Royal College of Obstetricians and Gynaecologists, London IDEAS Genetic Knowledge. 2009. Anomalies chromosomiques: Information pour les malades et leurs familles. Leuven: Orphanet. Fordította: Orphanet. http://www.eurogentest.org/fileadmin/templates/eugt/leaflets/pdf/french/chromosome_changes.pdf

Guy's and St Thomas' Hospital, the Royal College of Obstetricians and Gynaecologists, London IDEAS Genetic Knowledge. 2007. Hérédité dominante : Information pour les malades et leurs familles. Leuven: Orphanet. Fordította: Orphanet. http:// 
www.eurogentest.org/fileadmin/templates/eugt/leaflets/pdf/french/Dominant_Inheritance.pdf

Guy's and St Thomas' Hospital, the Royal College of Obstetricians and Gynaecologists, London IDEAS Genetic Knowledge. 2007. Hérédité récessive: Information pour les malades et leurs familles. Leuven: Orphanet. Fordította: Orphanet. http://www. eurogentest.org/fileadmin/templates/eugt/leaflets/pdf/french/recessive_inheritance.pdf

Guy's and St Thomas' Hospital, the Royal College of Obstetricians and Gynaecologists, London IDEAS Genetic Knowledge. 2009. Test génétique de porteur: Information pour les patients et les familles. Leuven: Orphanet. Fordította: Orphanet. http:// www.eurogentest.org/fileadmin/templates/eugt/leaflets/pdf/french/carrier_testing. pdf

Guy's and St Thomas' Hospital, the Royal College of Obstetricians and Gynaecologists, London IDEAS Genetic Knowledge. 2007. Translocations chromosomiques: Information pour les malades et leurs familles. Leuven: Orphanet. Fordította: Orphanet. http://www.eurogentest.org/fileadmin/templates/eugt/leaflets/pdf/french/ chromosome_translocations.pdf

Guy's and St Thomas' Hospital, the Royal College of Obstetricians and Gynaecologists, London IDEAS Genetic Knowledge. 2007. Qu'est-ce qu'un test génétique? Leuven: Orphanet. Fordította: Orphanet. http://www.eurogentest.org/fileadmin/templates/eugt/leaflets/pdf/french/genetic_test.pdf

Guy's and St Thomas' Hospital, the Royal College of Obstetricians and Gynaecologists, London IDEAS Genetic Knowledge. 2007. Questions fréquemment posées sur le test génétique: Information pour les malades et leurs familles. Leuven: Orphanet. Fordította: Orphanet. http:/www.eurogentest.org/fileadmin/templates/eugt/ leaflets/pdf/french/FAQ.pdf

International Society for Stem Cell Research. 2008. Guide à l'intention des patients sur les thérapies à base de cellules souches. Ottawa: Réseau de cellules souches. For- 
dította: Réseau de cellules souches. http://www.isscr.org/docs/default-source/patient-handbook/isscr_patientprimerhndbk_french_fnl.pdf

\section{A fordított magyar korpusz}

G.M. Durie, Brian. 2016. Mielóma multiplex, a csontvelö daganatos betegsége. Betegek kézikönyve. North Hollywood: International Myeloma Foundation. https://www. myeloma.org/sites/default/files/images/publications/International/PDF/hungarian/ phb_2016_hu.pdf

Guy's and St Thomas' Hospital, the Royal College of Obstetricians and Gynaecologists, London IDEAS Genetic Knowledge. 2009. A domináns öröklödés. Pécs: Orvosgenetikai Intézet, Pécsi Tudományegyetem. Fordította: Dr. Komlósi Katalin. http:// www.eurogentest.org/fileadmin/templates/eugt/leaflets/pdf/hungarian/Dominant_ Inheritance.pdf

Guy's and St Thomas' Hospital, the Royal College of Obstetricians and Gynaecologists, London IDEAS Genetic Knowledge. 2009. A magzatvizvizsgálat (amniocentesis). Pécs: Orvosgenetikai Intézet, Pécsi Tudományegyetem. Fordította: Dr. Komlósi Katalin. http://www.eurogentest.org/fileadmin/templates/eugt/leaflets/pdf/hungarian/amniocentesis.pdf

Guy's and St Thomas' Hospital, the Royal College of Obstetricians and Gynaecologists, London IDEAS Genetic Knowledge. 2009. Gyakran feltett kérdések a genetikai vizsgálattal kapcsolatban. Pécs: Orvosgenetikai Intézet, Pécsi Tudományegyetem. Fordította: Dr. Komlósi Katalin. http://www.eurogentest.org/fileadmin/templates/ eugt/leaflets/pdf/hungarian/FAQ.pdf

Guy's and St Thomas' Hospital, the Royal College of Obstetricians and Gynaecologists, London IDEAS Genetic Knowledge. 2009. Hordozóság szürés. Budapest: Országos Környezetegészségügyi Intézet, Molekuláris Genetikai és Diagnosztikai Osz- 
tály. Fordította: Dr. Karcagi Veronika PhD. http://www.eurogentest.org/fileadmin/ templates/eugt/leaflets/pdf/hungarian/carrier_testing.pdf

Guy's and St Thomas' Hospital, the Royal College of Obstetricians and Gynaecologists, London IDEAS Genetic Knowledge. 2007. Kromoszóma rendellenességek. Pécs: Orvosgenetikai Intézet, Pécsi Tudományegyetem. Fordította: Dr. Komlósi Katalin. http://www.eurogentest.org/fileadmin/templates/eugt/leaflets/pdf/hungarian/chromosome_changes.pdf

Guy's and St Thomas' Hospital, the Royal College of Obstetricians and Gynaecologists, London IDEAS Genetic Knowledge. 2009. Kromoszóma transzlokációk. Pécs: Orvosgenetikai Intézet, Pécsi Tudományegyetem. Fordította: Dr. Komlósi Katalin. http://www.eurogentest.org/fileadmin/templates/eugt/leaflets/pdf/hungarian/chromosome_translocations.pdf

Guy's and St Thomas' Hospital, the Royal College of Obstetricians and Gynaecologists, London IDEAS Genetic Knowledge. 2007. Mi az a genetikai teszt? Pécs: Orvosgenetikai Intézet, Pécsi Tudományegyetem. Fordította: Dr. Komlósi Katalin. http://www.eurogentest.org/fileadmin/templates/eugt/leaflets/pdf/hungarian/genetic_test.pdf

Guy's and St Thomas' Hospital, the Royal College of Obstetricians and Gynaecologists, London IDEAS Genetic Knowledge. 2009. Recesszív öröklödés. Pécs: Orvosgenetikai Intézet, Pécsi Tudományegyetem. Fordította: Dr. Komlósi Katalin. http:// www.eurogentest.org/fileadmin/templates/eugt/leaflets/pdf/hungarian/recessive inheritance.pdf

International Society for Stem Cell Research. 2008. Az Össejtkutatások Nemzetközi Szervezetének betegtájékoztatója az össejtterápiás lehetöségekröl. Fordította: [origo] Egészség. http://www.angyalszarnyak.hu/files/cikk73_ossejt_handbook.pdf 


\section{Internetes források}

http://www.webbeteg.hu/keresok/bno/13403

https://www.ipsennordic.com/en/therapeutic-areas/neurosciences/cervical-dystonia/ 
